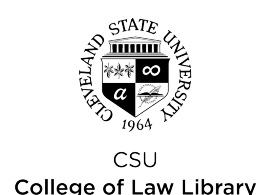

Cleveland State Law Review

Volume 57 | Issue 1

Article

2009

\title{
Use of Judicial Doctrines in Federal Tax Cases Decided by Trial Courts, 1993-2006: A Quantitative Assessment
}

Daniel M. Schneider

Northern Illinois University College of Law

Follow this and additional works at: https://engagedscholarship.csuohio.edu/clevstlrev

Part of the Taxation-Federal Commons

How does access to this work benefit you? Let us know!

\section{Recommended Citation}

Daniel M. Schneider, Use of Judicial Doctrines in Federal Tax Cases Decided by Trial Courts, 1993-2006: A Quantitative Assessment, 57 Clev. St. L. Rev. 35 (2009) available at https://engagedscholarship.csuohio.edu/clevstlrev/vol57/iss1/4

This Article is brought to you for free and open access by the Journals at EngagedScholarship@CSU. It has been accepted for inclusion in Cleveland State Law Review by an authorized editor of EngagedScholarship@CSU. For more information, please contact library.es@csuohio.edu. 
USE OF JUDICIAL DOCTRINES IN FEDERAL TAX CASES

DECIDED BY TRIAL COURTS, 1993-2006: A QUANTITATIVE ASSESSMENT

\section{DANIEL M. SCHNEIDER *}

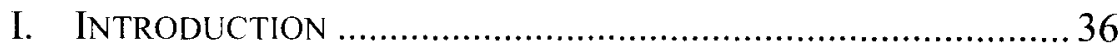

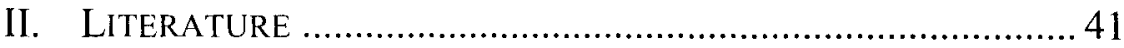

A. Introduction ............................................................... 41

B. Early Development .................................................... 43

C. Later Development of the Doctrines............................ 44

1. Substance Over Form ............................................. 44

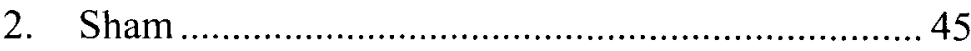

3. Business Purpose …............................................... 47

4. Economic Substance ............................................. 47

5. Step Transaction ................................................. 48

D. Codification of Judicial Doctrines................................. 48

E. The One-Way Street and a Taxpayer's Ability to

Disavow Form ......................................................... 49

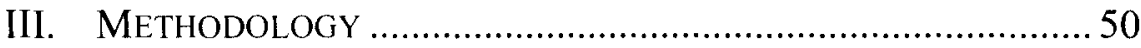

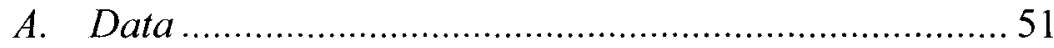

1. Cases Examined and Period Covered ..................... 51

2. Units of Analysis .................................................. 52

B. Variables and Other Information .................................. 52

C. Statistical Analyses ........................................................ 57

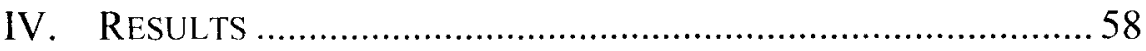

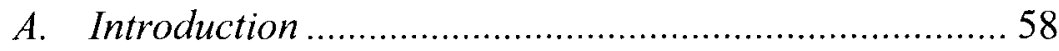

B. Who Raised a Doctrine and Did the Party Raising a Doctrine Want the Court to Apply the Doctrine? ....... 59

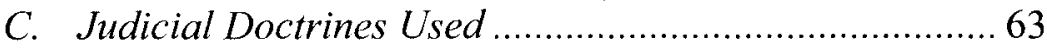

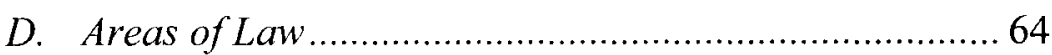

"Professor of Law, Northern Illinois University College of Law. I would like to thank members of the tax panel and audience at the 2008 Conference on Empirical Legal Studies for their comments, participants in the 2007 Critical Tax Conference at UCLA School of Law for their comments, and members of the panel and audience for "Lawyers and Doctrines: Some Ethical and Empirical Explorations of the Practice of Tax Law" at the 2005 Law \& Society Annual Meeting for their comments. I would also like to thank Beverly Moran, Guadalupe Luna, Marc Falkoff, David Taylor and Leandra Lederman for their comments on earlier drafts of this paper. Finally, I would like to acknowledge the assistance of two graduates of the College of Law, Mary Riley, Rebecca Davenport, and Andrew Welp in the preparation of this Article. 


\section{E. The One-Way Street Rule.............................................66 \\ F. Assessing Cause and Effect in the Database ................. 67 \\ V. CONCLUSION...................................................................... 70

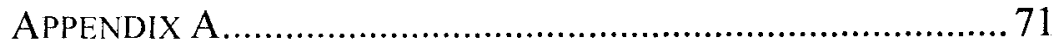

\section{INTRODUCTION}

Lawyers have argued about interpreting statutes as long as legislatures have enacted them and the Internal Revenue Code is not immune from these debates. When interpreting the Code, some approach the tax statutes narrowly, insisting on strict construction.' For others, Code sections have less literal meanings that can be discovered through a series of interpretive tools. ${ }^{2}$

Some of these interpretive devices, such as legislative history and administrative regulations, appear frequently in federal tax controversies. ${ }^{3}$ These methods depend upon material external to the statute-what Congress "thought" when it enacted a statute or how the Treasury Department interpreted a law. ${ }^{4}$ These tools also are neutral, because they are used to justify decisions in which both litigants-the government or the taxpayer-have won (but not at the same time on the same issue).$^{5}$

'See generally John F. Coverdale, Text as Limit: A Plea for a Decent Respect for the Tax Code, 71 Tul. L. Rev. 1501 (1997); Mary L. Heen, Plain Meaning, the Tax Code, and Doctrinal Incoherence, 48 Hastings L.J. 772 (1997) (noting the Supreme Court's increasing reliance on "plain meaning" of statute when deciding tax cases). See also Joseph Isenbergh, Musings on Form and Substance in Taxation, 49 U. CHI. L. REv. 859 (1982) (arguing against risks of non-literal interpretations).

${ }^{2}$ Rationalizing statutory interpretation is beyond the scope of this Article, but has a rich history and is implicit in any argument for wandering beyond the boundaries of a statute. For a recent, concise assessment about statutory interpretation, see generally William N. Eskridge, Ir., Book Review: No Frills Textualism, 19 Harv. L. Rev. 2041 (2006). For two excellent empirical studies of methods of interpretation used by the Supreme Court, see James J. Brudney \& Corey Ditslear, Canons of Construction and the Elusive Quest for Neutral Reasoning, 58 VAND. L. REV. 1 (2005) (labor law); Nancy Staudt et al., Judging Statutes: Interpretive Regimes. 38 LOYOLA LA. L. REv. 1909 (2005) (tax law).

'See generally Michael Livingston, Practical Reason, "Purposivism," and the Interpretation of Tax Statutes, 51 TAX L. REV. 677, Part II.B (1996) (arguing that tax is not an area of law subject to special rules of interpretation).

${ }^{4}$ See generally Michael Asimow, Public Participation in the Adoption of Temporary Tax Regulations, 44 TAX LAW. 343 (1991) (reviewing regulations in tax area); Bernard Wolfman, Note, Supreme Court Decisions in Taxation: 1980 Term, 35 TAX LAW. 443 (1982) (reviewing the use of regulations by Supreme Court); Beverly I. Moran \& Daniel M. Schneider, The Elephant and the Four Blind Men: The Burger Court and Its Federal Tax Decisions, 39 How. L.J. 841, 907-27 (1996) (reviewing the Burger Court's federal tax decisions and notes its reliance on regulations in its tax decisions).

${ }^{5}$ For examples of decisions about legislative history, compare National Mufflers Dealers Association v. United States, 440 U.S. 472, 484 (1979) (affording "serious deference" to regulation in light of legislative history; taxpayer lost) with Commissioner v. Engle, 464 U.S. 206, 220 (1984) (allowing taxpayer a depletion deduction by "measur[ing] against the legisłative process by which" the relevant law was enacted). Regarding regulations, compare 
Another common method of interpreting the Code is through "judicial doctrines," as might occur, for example, when a court determines that a corporate transformation does not qualify as a "reorganization" under Code $\$ 368$ and, therefore, does not enjoy the attendant tax benefits, because it lacks a "business purpose." The common wisdom about these judicial doctrines is that they are used only to justify decisions in favor of the government. They are not neutral because they cannot be used to rationalize decisions on behalf of the taxpayer. And, unlike the methods of construction just noted, they do not explicitly reach beyond the words of a statute, even if they set aside the effect of those words. ${ }^{7}$

The source for judicial doctrines used in federal tax controversies is Gregory v. Helvering. ${ }^{8}$ Evelyn Gregory tried to do what taxpayers always try to do-reduce her tax bill. Gregory owned a corporation, United Mortgage, which in turn owned stock of Monitor. Gregory wanted to own the Monitor stock directly but, if United Mortgage had simply distributed the stock to her as a dividend in order to give her possession of the stock - the most obvious route-she would have been taxed on the full amount of the distribution at a high rate of tax. Therefore, Gregory had United Mortgage engage in a "reorganization," the terminus of which still was her ownership of the Monitor stock. By engaging in this reorganization, Gregory believed that she could expose a smaller portion of the distribution to tax and incur tax at a lower rate."

National Mufflers Dealers Association v. United States, (upholding regulation and government won) with Commissioner of Internal Revenue v. First Security Bank of Utah, 405 U.S. 394 (1972) (finding reallocation of income required under regulation, but taxpayer won on facts of the case).

'See, e.g., Gregory v. Helvering, 293 U.S. 465 (1935).

${ }^{7}$ Another method of interpretation, textualism, also looks only to the statute. See generally Deborah A. Geier, Interpreting Tax Legislation: The Role of Purpose, 2 FLA. TAX REV. 492, 497, 502 (1995); Moran \& Schneider, supra note 4, at 928-42.

For a far-ranging article about interpreting the Code, see Staudt et al., supra note 2 (empirical research about Supreme Court tax decisions). See also Daniel M. Schneider, Statutory Construction in Federal Appellate Tax Cases: The Effect of Judges' Social Backgrounds and of Other Aspects of Litigation, 13 WASH. U. J.L. \& POL'Y 257 (2003) [hereinafter, Schneider, Statutory] (statutory construction in appellate decisions about federal tax); Daniel M. Schneider, Empirical Research About Judicial Reasoning: Statutory Interpretation in Federal Tax Cases, 31 N. M. L. REv. 325 (2001) [hereinafter Schneider, Empirical] (statutory construction in trial decisions about federal tax).

While interpreting statutes may raise questions about the institutional bias of the method used, textualism suggests a deference to the legislature or reliance on administrative pronouncements, and reveals a bias towards the executive branch, but that discussion is beyond the scope of this article. Judges disregarding statutes' language, as they do when applying judicial doctrines, reveals a tilt towards the judiciary. For an excellent discussion about institutional biases, with an eye towards tax, see Staudt et al., supra note 2.

${ }^{8} 293$ U.S. 465 (1935). While Gregory is considered a seminal case, judicial doctrines were used even before Gregory. See infra note 39 (notes pre-Gregory authority).

"Gregory had United Mortgage engage in a reorganization by placing some of its assets-the Monitor stock-into another corporation, Averill, created solely to facilitate the transfer of Monitor stock to her. Revenue Act of $1928 \$ 112(i), 45$ Stat. 798. The Averill stock was distributed by United Mortgage to Gregory, and she took the position that she should not be 
Gregory's place in the development of judicial doctrines is secured because of how the Supreme Court justified deciding that a reorganization had not taken place. While Gregory had technically engaged in a reorganization, the Supreme Court determined that the transaction exalted "artifice above reality" and lacked a "business . . purpose." 10 Gregory therefore was taxed on what she had received absent a reorganization, a dividend.

As the seminal case, Gregory both suggests and illustrates the accepted wisdom about "judicial doctrines," that they are invariably used on behalf of the government because taxpayers control the transactions and can therefore determine the mode of taxation. Taxpayers, the reasoning goes, rely on statutes' literal terms in order to secure predictable results. Because non-literal readings derived from judicially created doctrines that work exclusively in the government's favor, only the government or the court, when it intends to decide on behalf of the government, would ever invoke a judicial doctrine." ${ }^{11}$ But for a few, strictly circumscribed situations in which taxpayers may assert doctrines (e.g., fraud, mistake), ${ }^{12}$ judicial tax doctrines exist to service the government.

The forms of judicial doctrines most commonly cited since Gregory are:

- business purpose;

- economic substance;

- sham transaction:

- step transaction; and

- substance over form.

taxed on receipt of that stock because she had received it as part of a reorganization. Id. $\S$ 112(g). When she liquidated Averill a few days after the distribution of its stock to her and, therefore, received its asset- the Monitor stock - taxation was then appropriate, but only on the amount of her gain in the transaction (the value of the Monitor stock minus what she was considered to have paid for it (her "basis")) and at capital gains rates. These facts are set out more fully in the Second Circuit decision which Gregory appealed to the Supreme Court. Helvering v. Gregory, 69 F.2d 809 (2d Cir. 1934).

Gregory's situation may be illustrated by assuming that a corporation alternatively makes a $\$ 100$ dividend distribution to its shareholder or exchanges $\$ 100$ for an asset in which the taxpayer's basis is $\$ 20$ in a transaction that is not characterized as a dividend. The amount of the dividend subject to tax is $\$ 100$, while the amount of gain (presumably, capital gain) subject to tax is $\$ 80$. See I.R.C. $\$ \$ 301$ (b) (amount of dividend), 1001(a) (gain realized and recognized) (2000). Both dividends and capital gain are currently subject to a maximum tax rate of fifteen percent, but that does not lessen the benefit of characterizing the shareholder's income as capital gain, because a smaller amount is subject to tax. See I.R.C. $\$ 1(\mathrm{~h})$ (1) (capital gains) - (11) (dividends) (2000). The fifteen percent tax on the $\$ 100$ dividend is $\$ 15$, while the fifteen percent tax on the $\$ 80$ capital gain is $\$ 12$. Capital gains are frequently taxed at lower rates than dividends, however, as when Gregory engaged in her "reorganization." See generally Boris I. BITTKER \& LAWRENCE LOKKEN, FEDERAL TAXATION OF INCOME, EsTATES AND GIFTS 9 46.2, 46.2.1 (3d ed. 2000). A lower tax rate enhances the benefit of a capital gain.

${ }^{10}$ Gregory, 293 U.S. at 469-70. The Supreme Court affirmed the Second Circuit, which determined "the transactions were no part of the conduct of the business of either or both companies; so viewed they were a sham." Gregory, 69 F.2d at 811 .

\footnotetext{
"See infra note 80.

${ }^{12}$ See infra Part II.E.
} 
They are labeled judicial doctrines, to state the obvious, because they were devised by judges, unlike guidelines promulgated by an agency, such as regulations, or that arose against the background of how the Code is enacted, as is legislative history. As in Gregory, courts theoretically use these doctrines to refute the consequences that flow from accepting a taxpayer's strict compliance with the terms of a statute. Because, for example, the taxpayer does not possess a "business purpose" for what she did or because the "economic substance" or the "substance as opposed to the form" of the transaction is other than as the taxpayer intended, the taxpayer is denied the benefit of the transaction for which she intends to qualify.

The hypothesis of this Article is that the accepted wisdom-that judicial doctrines are raised exclusively by the government or the courts for the government's benefit-is wrong. Instead, judicial doctrines are used in a much richer manner by courts and by taxpayers, as well as the government, than the "wisdom" would suggest. It is the first paper to question the accepted thought about judicial doctrines and to do so using social science methodology. Starting at the end and working forward, the evidence assembled for this Article from a group of trial decisions about federal tax controversies establishes that, under the language of the judges' opinions, taxpayers frequently raise judicial doctrines. Sometimes arguing that the doctrines should be applied and sometimes arguing that they should not, ${ }^{13}$ taxpayers often are able to prevail in their arguments. ${ }^{14}$ In other words, the data negate the accepted wisdom. The "sword" wielded by the government has a second edge, perhaps not as sharp as the government's, but nevertheless honed by the taxpayer for its use against the government. Indeed, circumstances can be predictably associated with the litigants prevailing in having judicial doctrines applied for their benefit, most notably the taxpayer prevailing when the business purpose or sham transaction doctrines are used. When a party raises a doctrine and also when the party raising a doctrine wants the court to apply the doctrine on behalf of a litigant, that litigant is likely to prevail in the doctrine's application.

What accounts for this discrepancy between perception and reality? There are two answers to this question, one narrow and the other general. More specifically, judicial tax doctrines' alleged bias towards the government is derived from numerous articles and essays which, in turn, uniformly promote the common wisdom. ${ }^{15}$ The authors of these articles and essays base their views on specific cases or strings of cases, not the entire universe of cases about judicial doctrines or even a broader sampling of such cases. ${ }^{16}$ Furthermore, the literature is grounded in legal reasoning, a formalistic approach which may enable us to shape concepts efficiently, but at the apparent cost of excluding cases invoking judicial doctrines that do not fit the model. To draw from one of the judicial doctrines explained below, legal reasoning may help clarify what constitutes a business purpose, ${ }^{17}$ but it does so by examining relatively few cases about the doctrine, not all of them, and so legal reasoning may

${ }^{13}$ See infra fig. 2 .

${ }^{14}$ See infra note 114.

${ }^{15}$ See infra Part II (discussing literature).

${ }^{16}$ Doctrines, and not just individual cases, are occasionally analyzed, but few attempts have been made to examine judicial doctrines broadly. See infra note 24.

${ }^{17}$ See infra Part II.C.3. 
not offer an accurate picture of how the business purpose doctrine is used (and, in fact, does not).

More broadly, the current literature about judicial doctrines underscores tax scholarship's failure to inquire other than as it has always done, here by using quantitative social science methodology. Were the literature that girds judicial tax doctrines is simply accepted, one would not understand that taxpayers are empowered to assert these doctrines, even when they cannot prove fraud or mistake. The data assembled for this Article comes from a broad swatch of cases-all trial decisions available on-line from a fourteen year period-and sifts for patterns among those cases and the accompanying briefs. While much can be said about traditional legal scholarship, this research adds to it by making clear that judicial doctrines are used complexly by the government, taxpayers, and judges in ways not addressed by the authors of traditional tax scholarship. Those authors who have used social science methodology in order to describe other aspects of tax have been able to inform us of trends in Supreme Court decisions about tax ${ }^{18}$ how appellate and trial courts have decided tax cases and whether who the judges were might have influenced the judges to decide in favor of the taxpayer or the government ${ }^{19}$ or how they justified the decisions, ${ }^{20}$ and what might have led to settling cases brought in the Tax Court. ${ }^{21}$ They, too, have identified patterns not presented by those who have engaged in traditional legal scholarship. ${ }^{22}$

This Article is also intended to prompt discussion about how judicial doctrines are used in federal tax opinions and to act as a platform for further research. In addition to the obvious question of whether the results can be replicated in another database, will other results emerge? Would refining the questions posed lead to more finely etched results? Would a more comprehensive database lead to more nuanced conclusions?

The remainder of this Article is divided into four parts. First, the literature regarding use of judicial doctrines in tax is summarized. Next, the methodology used to create the database is set forth. Third, results are laid out. And, finally, the paper concludes, both summarizing the data and suggesting areas that merit further examination.

\footnotetext{
${ }^{18}$ See Staudt et al., supra note 2.
}

${ }^{19}$ Daniel M. Schneider, Using the Social Background Model to Explain Who Wins Federal Appellate Tax Decisions: Do Less Traditional Judges Favor the Taxpayer?, 25 VA. TAX REV. 201 (2005) [hereinafter, Schneider, Social Background]; Daniel M. Schneider, Assessing and Predicting Who Wins Federal Tax Trial Decisions, 37 WAKE FOREST L. REv. 473 (2002) [hereinafter, Schneider, Assessing].

${ }^{20}$ Schneider, Statutory, supra note 7; Schneider, Empirical, supra note 7.

${ }^{21}$ Leandra Lederman, Which Cases Go to Trial?: An Empirical Study of Predictors of Failure to Settle, 49 CASE W. RES. L. Rev. 315 (1999).

${ }^{22}$ See generally Mark A. Hall \& Ronald F. Wright, Systematic Content Analysis of Judicial Opinions, 96 CAL. L. REV. 63 (2008) (arguing for "content analysis," and combining social science methodology with legal research). Another attractive theory is new legal realism. See generally Howard Erlanger et al., New Legal Realism Symposium: Is It Time for a New Legal Realism?', 2005 WIS L. REV. 335, 339-45 (2005) (calling for empirical research, but still an engagement of realism with policy). 


\section{LITERATURE}

The articles and essays written about judicial tax doctrines are doctrinal or normative and tend to describe issues such as the development of the economic substance doctrine or variations of the step transaction doctrine. They do not, however, reveal the types of conclusions that may be drawn from empirically oriented research. ${ }^{23}$ They fail to comprehend taxpayers' (occasionally successful) assertions of judicial doctrines and of patterns surrounding these assertions - by any party-and use and possible associations between these assertions and litigants' prevailing in how doctrines are applied. ${ }^{24}$ The data presented in this Article cannot be understood without knowing about what exists, and so Part II of this Article describes the current literature. ${ }^{25}$ Set forth below are an introduction to literature about judicial doctrines, descriptions of the doctrines' origins and development, and analysis of taxpayers' inability to disavow the form of the transaction they have cast. $^{26}$

\section{A. Introduction}

When establishing one's obligations in our voluntary system to pay income tax, a line can be drawn from denial to acceptance of that responsibility. ${ }^{27} \mathrm{~A}$ taxpayer who (understandably) is reluctant to accept her obligation to pay a tax may choose either to evade or just avoid it. The "lesser" of these evils-avoidance-may be said to represent a taxpayer's lawful attempt to reduce tax. ${ }^{28}$ Clearly legitimate examples of

${ }^{23}$ See supra text accompanying notes $15-22$.

${ }^{24}$ Compare, e.g., Gregory v. Helvering, 293 U.S. 465 (1935) (finding adequate proof by government and government won), discussed supra text accompanying notes 8-10, with Chisholm v. Comm'r, 79 F.2d 14, 15 (2d Cir. 1935), cert. denied, 296 U.S. 641 (1935) (finding failure of proof by government and taxpayer won), discussed infra text accompanying note 43.

For the few examples of the broad views taken in this area, see generally BITTKER \& LOKKEN, supra note 9, at 4.3.1; RANDOLPH E. PAul, STUdies IN FEDERAL TAXATION (1937).

${ }^{25}$ See also Staudt et al., supra note 2 , at 1912, n. 10 (looking at "the actual-as opposed to assumed" methods of interpreting the Code or what "is" instead of what "ought" the law be. (citation omitted)).

${ }^{26}$ Other than that altering the form of a transaction is a one-way street, running in the government's direction, infra Part II.E, there does not appear to be any difference among the doctrines based on whether the government, the court, or the taxpayer raises them. Substance over form, for example, is the same in each party's hands. As is noted below, infra text following note 115 , the taxpayer is theoretically unable to argue for application of the business purpose, economic substance or sham transaction doctrines.

${ }^{27}$ See Bullen v. Wis., 240 U.S. 625, 630-631 (1916).

${ }^{28}$ See id. (finding evasion on wrong side of the line; presumably, avoidance is not). See also PAUL, supra note 24, at 9. Randolph Paul is credited with clarifying (and maintaining) the difference between tax avoidance and tax evasion, so that the interchangeable use of the terms has ceased. See Harrop A. Freeman \& Lewis H. Kirschner, An Ounce of Prevention: A Study in Corporate Tax Avoidance, 46 COLUM. L. REv. 951, 952, n.5 (1946) (underscoring Paul's importance in distinguishing between the two concepts). See generally BITTKER \& LOKKEN, supra note 9, at \4.3.1. 
avoidance include taking advantage of a statutory scheme ${ }^{29}$ or qualifying a transaction under a statute for favored tax status. ${ }^{30}$ Less legitimate instances are resisted by the government, at least when taxpayers' transgressive behaviors becomes apparent. Tax avoidance is not inappropriate; as Judge Learned Hand (famously) said, "there is nothing sinister in so arranging one's affairs as to keep taxes as low as possible. Everybody does so, rich or poor; and all do right, for nobody owes any public duty to pay more than the law demands." ${ }^{31}$ These observations having been made, it is also apparent that taxpayers, the government, and courts have devoted substantial resources to ascertaining where on this line taxpayers place themselves. ${ }^{32}$

Statutory rules cannot encompass every transaction if they address only the objective requirements of taxpayer compliance. Gregory's attempted reorganization illustrates this point, since the transaction literally met the terms of the statute, but still failed to qualify for its benefits. ${ }^{33}$ While the Code sometimes uses less specific rules to establish tax liability, ${ }^{34}$ our tax system tends to rely on ascertainable statutory standards, such that the "softer" guidelines that leaven the Code are usually found elsewhere. ${ }^{35}$ Judicial doctrines are a source for these more subjective signposts that direct taxpayers towards appropriate behavior. As noted, the most common judicial tax doctrines, and those examined in this article, are: business purpose, economic substance, sham transaction, step transaction, and substance over form. ${ }^{36}$

\footnotetext{
${ }^{29}$ E.g., I.R.C. $\$ \$ 71,215(2000)$ (discussing a higher tax bracket taxpayer's payment of alimony instead of child support to custodial ex-spouse in a lower tax bracket, in order to subject income paid to lower rate of tax).

${ }^{30}$ E.g., Being married or a partner, so that recognition of gain may be avoided when transferring property to one's spouse or to the partnership. I.R.C. $\S \S 1041$ (a) (marriage), 721 (partnership) (2000).

${ }^{31}$ Comm'r v. Newman, 159 F.2d 848, 850-51 (2d Cir. 1947) (Hand, L., dissenting), cert. denied, 331 U.S. 859 (1947).

${ }^{32}$ Tax avoidance necessarily entails intent because a taxpayer plans to minimize, or avoid, tax, instead of awakening one day and discovering it just happened; but other causes of tax avoidance include societal sensitivity to the activity and the government's need to raise revenue. See Assaf Livhovski, The Duke and the Lady: Helvering v. Gregory and the History of Tax Avoidance Adjudication, 25 CARDozo L. REv. 953, 991-995 (2004); Joseph Bankman, The Economic Substance Doctrine, 74 S. CAL. L. Rev. 5 (2000); Harry J. Rudick. The Problem of Personal Income Tax Avoidance, 7 LAW \& ConTemp. Probs. 243, 245 (1940); PAul, supra note 24 , at 74-79, 86 .

${ }^{33}$ See Gregory v. Helvering, 293 U.S. 465, 469-470 (1935).

${ }^{34}$ See, e.g., David P. Hariton, Sorting Out the Tangle of Economic Substance, 52 TAX LAW. 235, 238, n.7 (1999) (citing I.R.C. $\$ \$ 446(b), 269,7701$ (f)).

${ }^{35}$ See id. at 236-37. For more analysis of the tension between the text of the Code and nonliteral interpretations of it, see Noel B. Cunningham \& James R. Repetti, Textualism and Tax Shelters, 24 VA. TAX REV. 1 (2004); Allen D. Madison, The Tension Between Textualism and Substance-Over-Form Doctrines in the Tax Law, 43 SANTA Clara L. REV. 699 (2003); Heen, supra note 1.

${ }^{36}$ See supra text following note 12 (lists doctrines). For the typicity of these doctrines, see, e.g., BITTKER \& LOKKEN, supra note 9 , at 94.3 (discussing separately substance over form, business purpose, economic substance and step transaction). Much of the earlier literature
} 


\section{B. Early Development}

Gregory v. Helvering ${ }^{37}$ is usually thought of as the seminal case on judicial doctrines in tax. ${ }^{38}$ But a review of decisions rendered before Gregory and of the literature that analyzes those decisions reveal the earlier existence of these doctrines and, more importantly, the tension-between reading statutes literally and unintended results that flow from such strict construction-with which these doctrines were designed to cope. ${ }^{39}$

In some ways, Gregory reflects an exercise in line-drawing. Not long before it was decided, Justice Holmes wrote, in Bullen v. Wisconsin ${ }^{40}$ :

We do not speak of evasion, because, when the law draws a line, a case is on one side of it or the other, and if on the safe side is none the worse legally that a party has availed himself to the full of what the law permits.

focused on avoidance in various areas, such as corporate tax, whether in the formalities attached to that form of doing business or to reorganizations, or individual taxation. Regarding corporate tax, see, e.g., Norris Darrell, Recent Developments in Nontaxable Reorganizations and Stock Dividends, 61 HaRV. L. REv. 958 (1948); Richard W. Case, Disregard of Corporate Entity in Federal Taxation. The Modern Approach, 30 VA. L. REV. 398 (1944); Milton Sandberg, The Income Tax Subsidy to 'Reorganizations,' 38 CoLum. L. REV. 98 (1938); Maurice Finkelstein, The Corporate Entity and the Income Tax, 44 YALE L.J. 436 (1935); Note, Income Taxation: Recognition of Gain or Loss in Corporate Reorganizations, 24 VA. L. Rev. 418 (1938); Note, Taxation: Income Tax. Tax Effect of Reorganization Provisions, 37 Colum. L. REv. 142 (1937). And, as to personal tax, see, e.g.. Charles L.B. Lowndes, Tax Avoidance and the Estate Tax, 7 LAW \& ConTEMP. Problems 309 (1940); Rudick, supra note 32; Note, Proposals for Preventing Family Tax Avoidance, 57 YALE L.J. 788 (1948); Note, The Tax Reduction Motive within the Family Unit, 47 Colum. L. REv. 665 (1947); Note, Intra-Family Assignments and Income Taxation: Use of the Corporate Form as a Means of Tax Avoidance, 57 YALE L.J. 308 (1947); Note, Taxation. Losses Established for Income Tax Purposes by Indirect Sales between Members of a Family, 33 VA. L. Rev. 95 (1947). See generally JoInt H. S. Comm. ON TAXATION, Description AND analysis of Present-Law Tax Rules and Rlcent Proposals Relating to Corporate TAX SHElters, JCX-84-99 (Comm. Print 1999), available at http:/www.irs.gov/pub/irsutl/ii.b__ judicial_doctrines_ii.pdf.

${ }^{37}$ Gregory v. Helvering, 293 U.S. 465 (1935).

${ }^{38}$ See, e.g., BITTKER \& LOKKEN, supra note 9, at 9 9 4.3 .3 (discussing form versus substance), 4.3.4 (discussing business purpose); Bankman, stupra note 32, at 7-8 (discussing economic substance).

${ }^{39}$ See, e.g., United States v. Phellis, 257 U.S. 156, 168 (1921) (discussing substance versus form), cited in BITTKer \& LOKKEN, supra note 9, at 4.3.3, n.30; RANDOL.PH E. PAUL, SElected Studies in Federal TAXation, (2d Series 1938) (containing numerous citations to pre-Gregory cases in discussion of step transaction); Marvin A. Chirelstein, Learned Hand's Contribution to the Law of Tax Avoidance, 77 Y ALE L.J. 440, 441 (1968) (stating Judge Hand's contribution to discussion of substance versus form began "with an opinion involving the Corporate Excise Tax of 1909" decided in 1918 (citation omitted)).

${ }^{40} 240$ U.S. 625 (1916) (finding Wisconsin able to impose inheritance tax on out-of-state trust of decedent, who had been a Wisconsin resident before he died). 
When an act is condemned as an evasion what is meant is that it is on the wrong side of the line. ${ }^{41}$

He continued, however, by stating that the "wrong side" is "indicated by the policy if not by the mere letter of the law," thereby underscoring the ephemeral nature of the line, in case anyone had naïvely thought it had been drawn sharply.

While Gregory had not engaged in tax evasion, what she did was still deemed tax avoidance and so was on that side of a line in which intended tax benefits were disallowed. Chisholm v. Commissioner, ${ }^{43}$ a case contemporaneous with Gregory, illustrates the other side. The Chisholm taxpayers were among those who formed a partnership for which their admitted intent was to avoid the taxes that they otherwise would have incurred if they, instead of the partnership, sold stock that they had contributed to the partnership. Because the partners also possessed the intent to conduct business through the partnership, however, the partnership's gain (under then applicable law) was not taxed to the partners.

As commentators drew these early lines, they paid some attention to where these doctrines arose, and so some articles clustered around suspect areas, such as corporate tax, use of the family, and personal income. ${ }^{44}$ In many ways, early cases and commentary about judicial doctrines revealed what would occur as these doctrines continued to develop.

\section{Later Development of the Doctrines}

Judicial tax doctrines continued to be used and expanded after Gregory was decided in 1935. The doctrines persevere, as they have been invoked recently to combat tax shelters, especially corporate tax shelters. ${ }^{45}$

\section{Substance Over Form}

Honoring form is not inevitably fatal; formal choices frequently are respected and, indeed, encouraged. . $^{40}$ But relying on the "substance" of a transaction instead of

${ }^{41}$ Id. at 630-31. See generally David A. Weisbach, An Economic Analysis of Anti-TaxAvoidance Doctrines, 4 AM. L. \& ECON. REv. 88 (2002); David A. Weisbach, An Efficiency Analysis of Line Drawing in the Tax Law, 29 J. LEGAL STUD. 7 ( (2000).

${ }^{42}$ Bullen v. Wis., 240 U.S. 625, 631 (1916).

1.79 F.2d 14, 15 (2d Cir. 1935), cert. denied, 296 U.S. 64 (1935).

${ }^{44}$ See supra note 36.

${ }^{45}$ See infra note 75. See gencrally Boris I. BITTKER \& JAMES S. EUSTICE, FEderal INCOME TAXATION OF CORPORATIONS ANI) SHAREHOLDERS 5.10 (7th ed. 2000) (discussing corporate tax shelters and various responses to them). See also Jason Quinn, Comment, Being Punished for Obeving the Rules: Corporate Tax Planning and the Overly Broad Economic Substance Doctrine, 15 GEo. MASON L. REv. 1041 (2008) (discussing the seemingly disproportionate amount of victories by the government compared to individuals when judicial doctrines are invoked); Timothy R. Hicks, Comment, Government Victories Using the Economic Substance Doctrine: A Changing of the Tide in Tax Practice, 38 Clumb. L. Rev. 101 (2007) (same).

${ }^{t h} E$.g., Formerly married taxpayers may reduce overall tax by having the higher bracket taxpayer pay alimony instead of ehild support to the lower bracket taxpayer. Formal requirements for alimony and child support are set forth at I.R.C. \$7l(b)-(c) (2000) but, if met, the tax reduction is permitted. 
its "form" may lead, as it did in Gregory, to taxing someone on receipt of stock received in a corporate reorganization as a dividend - a less apparent result--instead of permitting non-recognition of the gain from the receipt-the more obvious outcome. Because Gregory received something upon which she should have been taxed, the umbrella of non-recognition, technically and formally available to reorganizations, was not applicable because the substance of what she had done was not really a reorganization. ${ }^{47}$

Another benchmark of this doctrine, decided twenty-five years after Gregory, is Knetsch v. United States. ${ }^{48}$ Knetsch bought annuity bonds, largely with money he borrowed, on which he was charged 3.5 percent interest and for which the security was the cash surrender value of the bonds, even though the bonds only paid 2.5 percent interest. He wanted to take a large deduction quickly in order to diminish the amount of otherwise taxed current income and was able to achieve his goal by paying a point more to borrow money than he would receive from the purchased instrument. Knetsch failed to offer evidence of another, nontax reason for the transaction, and so the Supreme Court disallowed his deduction because "there was nothing of substance to be realized by Knetsch from this transaction beyond a tax deduction."

Immediately after conceding the difficulty of summarizing substance over form cases, Professors Bittker and Lokken (authors of a standard federal tax treatise) suggest that a common thread among these cases may be that the government most often succeeds in asserting the doctrine when transactions take place between related parties. $^{50}$ While the Tax Court has attempted to articulate an objective test for applying the doctrine by listing several criteria, Bittker and Lokken still reduce the reason to reject the doctrine's application to instances where "a transaction is consummated in a form that fairly reflects its substance," even if the taxpayer has chosen the form to obtain greater tax benefits. ${ }^{51}$

\section{Sham}

Sometimes a transaction is disregarded because it is considered a sham. In a case where this doctrine was not used, Frank Lyon Co. v. United States, ${ }^{52}$ the Supreme

\footnotetext{
${ }^{47}$ See Helvering v. Gregory, 69 F.2d 809, 809-10 (2d Cir. 1934), aff'd, 293 U.S. 465 (1935) (clearer statement in appellate decision than Supreme Court opinion of litigants' positions).

${ }^{48} 364$ U.S. 361 (1960).

${ }^{49} I d$. at 366. See generally Walter J. Blum, Knetsch v. U.S.: A Pronouncement on Tax Avoidance, 40 Taxes 296 (1962); Walter J. Blum, Knetsch v. U.S.: A Pronouncement on Tax Avoidance, Sup. Cr. REV. 135 (1961).

${ }^{50}$ BITTKER \& LOKKEN, supra note 9, at 4.3.3.

${ }^{51} I d$. at 4-40, n.60, noting Grodt \& McKay Realty, Inc. v. Comm'r, 77 T.C. 1221 (1981). See also Esmark, Inc. v. Comm'r, 90 T.C. 171 (1988), aff'd, 886 F.2d. 1318 (7th Cir. 1989) (form chosen by taxpayer disregarded and court taxed it on most expensive form that led to same economic consequence; substance of transaction not altered in the process). Bittker and Lokken, however, suggest that this extension of the substance over form doctrine is not much followed. BITTKER \& LOKKEN, supra note 9, at $4.3 .3 \mathrm{nn}$. 72-73.
}

${ }^{52}$ Frank Lyon Co. v. United States, 435 U.S. 561 (1978). 
Court refused to treat a taxpayer's purchase and leaseback of a building back to the seller as a sham because regulatory constraints had been imposed on the seller and because multiple parties were involved, each with competing interests. ${ }^{53}$

If external forces that impose a particular form onto a transaction negate characterizing it as a sham, what, then, is a sham? Case law establishes two types, shams in substance and shams in fact, the difference between them being that "shams in fact are transactions that never occur [while].. . shams in substance are transactions that actually occurred but which lack the substance their form represents." 54 The leading Supreme Court decision in the area just noted, Frank Lyon, addressed what constituted sham in fact, and concluded that it could test for such a sham by applying a two-step test. As the Fourth Circuit in Rice's Tovota World v. Commissioner then characterized Frank Lyon:

To treat a transaction as a sham, the court must find that the taxpayer was motivated by no business purposes other than obtaining tax benefits in entering the transaction, and that the transaction has no economic substance because no reasonable possibility of a profit exists. ${ }^{55}$

Courts have applied this test in many ways. As Rice's Toyota World suggests, the sham transaction doctrine applies only if there is no business purpose for, and no economic substance to, the transaction. ${ }^{56}$ Other courts, however, have viewed the doctrine differently, suggesting that the sham transaction doctrine applies even if only one of the two tests is met ${ }^{57}$ or if the transaction possesses "economic effects" (instead of "economic substance") but lacks a business purpose. ${ }^{58}$ And some courts simply scrutinize transactions more closely. ${ }^{59}$ Even assuming that the appropriate standard for the sham transaction doctrine has been ascertained, how to define the appropriate standard-business purpose and/or economic substance/effects--remains to be decided. ${ }^{60}$

${ }^{53} I d$ at $581-84$.

${ }^{54}$ Kirchman v. CIR, 862 F.2d 1486, 1492 (11th Cir. 1989).

${ }^{55}$ Rice's Toyota World, Inc. v. Comm'r. 752 F.2d 89, 91 (4th Cir. 1985) (citation omitted) (emphasis added).

${ }^{56} \mathrm{Id}$.

${ }^{57}$ IES Indus. Inc. v. U.S., 253 F.3d 350 (8th Cir. 2001).

${ }^{58}$ United Parcel Serv. v. Comm'r, 254 F.3d 1014 (11th Cir. 2001), cert. denied, 535 U.S. 986 (2002). See also Coltec Indus., Inc. v. U.S., 454 F.3d 1340 (Fed. Cir. 2006) (economic substance, not economic effects); H.J. Heinz Co. v. U.S., 76 Fed. Cl. 570 (2007) (sham transaction existed); Ethan Yale, Was Heinz's Two-Step Redemption a Sham?, 117 TAX NotFS 345 (2007) (arguing that application of sham transaction was argued by government too aggressively).

${ }^{59}$ ACM P'ship v. Comm'r, 157 F.3d 231 (3d Cir. 1998), cert. denied, 526 U.S. 1017 (1999).

${ }^{60}$ Both of those doctrines are discussed below, infra Parts II.C.3-4. See generally BITTKER \& LokKen, supra note 9, at 4.3.4A; Peter J. Connors et al., Recent Cases Involving the Economic Sham Transaction Doctrine-Or Whatever They Are Calling It Now, in 10 TAX Strategies for Corporate ACQuisitions, Dispositions, Spin-OfFs, Joint Vintures, Financings, Reorganizations \& REstructuring; 1261 (2004). 


\section{Business Purpose}

Lack of a business purpose for the corporate division was one of the reasons the taxpayer lost in Gregory. ${ }^{61}$ In Goldstein v. Commissioner, ${ }^{62}$ Goldstein, like the Knetsch taxpayer, ${ }^{63}$ tried to deduct an expense in order to minimize tax on a substantial amount of income (caused by winning the Irish Sweepstakes). Also as in Knetsch, Goldstein borrowed, and paid interest of 1.5 percent, to buy bonds that paid 0.5 percent interest, using the bonds as collateral for the loan. The Second Circuit decided in favor of the government and, while its decision was specific to Code $\$$ 163 , its opinion applies more generally as well. The court perceived a Congressional policy in encouraging people to borrow, but also demanded "some substance to the loan arrangement beyond the taxpayer's desire to secure the deduction," for which borrowing at a rate that exceeded the return on the investment, even taking appreciation into account, was inadequate evidence. ${ }^{14}$ Thus, a taxpayer's mere, and sole, intent to reduce taxes exposes her planned transaction to the business purpose doctrine.

\section{Economic Substance}

The Circuits are presently divided on what test should be used in deciding whether a transaction lacks economic substance. ${ }^{65}$ In a recent articulation of the economic substance test, $A C M$ Parmership v. Commissioner, ${ }^{66}$ the Third Circuit said:

The inquiry into whether the taxpayer's transactions had sufficient economic substance to be respected for tax purposes turns on both the "objective economic substance of the transactions" and the "subjective business motivation" behind them . ... However, these distinct aspects of the economic sham inquiry do not constitute discrete prongs of a "rigid two-step analysis," but rather represent related factors both of which inform the analysis of whether the transaction had sufficient substance. apart from its tax consequences, to be respected for tax purposes. ${ }^{67}$

${ }^{61}$ See Gregory v. Helvering, 293 U.S. 465 (1935)

${ }^{62}$ Knetsch v. United States, 364 F.2d 734 (2d (ir 1966), cert. denied, 385 U.S. 1005 (1967).

${ }^{6.3} I d$.

${ }^{64} I d$. at 740-42. Interestingly, based upon the facts (essentially, the substance of these loans were that they were loans). the court declined to characterize the scheme as a sham. $I d$. at $737-40$.

${ }^{65}$ See Hicks, supra note 45, at 111.

${ }^{66} 157$ F.3d 231 (3d Cir. 1998). See generally Bankman, supra note 32; Hariton, supra note 34 .

${ }^{67} A C M$ P'ship, 157 F.3d at 247. Bankman suggests that the "current version" of the economic substance doctrine can be traced to this decision. Bankman, supra note 32 , at 8 . See generally Richard M. Lipton, Cotntryside: The Tax Court Rejects an IRS Challenge to the Economic Substance of a 'Real Deal,' 108 J. Tax"N 137 (2008); Dennis J. Ventry, Jr., Saring the Economic Substance Doctrine from Congress, 118 TAX NoTEs 1405 (2008); David P. 
The court continued, defining the objective criterion as whether the transaction had any practical economic effect, other than generating a deduction for a loss, and the subjective one as whether the taxpayer had any business purpose, which it did not. ${ }^{68}$ The Fifth, Ninth, and Tenth Circuits agreed with the Third that a two prong approach is not required to find lack of economic substance. ${ }^{69}$ However, the First, Sixth, Seventh, Eighth, and Eleventh Circuits have held that the two different prongs of the test must both exist to satisfy the economic substance test ${ }^{70}$; the Second and Fourth Circuits only require one. ${ }^{11}$

\section{Step Transaction}

While one may say, half seriously, that the step transaction doctrine is the most finely etched of judicial tax doctrines, the truth of this assertion lies more in the clarity of the doctrine's articulation than in its application. There are three varieties of the step transaction doctrine, all of which may be reduced to showing that the steps taken by the taxpayer in a transaction were motivated by tax considerations, and that the form of the transaction should be disregarded when assessing the tax liability of the taxpayer. In the variations of the step transaction doctrine test, one either looks at the end result of multiple transactions, for steps that are mutually interdependent, or for steps for which there are binding commitments; interestingly, all of these tests appear to have been recognized as early as the 1930s. ${ }^{72}$ The step transaction doctrine pervades several areas of tax law, especially corporate tax and estate planning, but has been used more prominently in recent years in cases involving corporate tax and complicated financial and business transactions. ${ }^{73}$

\section{Codification of Judicial Doctrines}

Some commentators have called for "codification" of judicial doctrines, either by amending the Code or by issuing new regulations, in order to minimize problems caused by the patchwork character of judicial doctrines. ${ }^{74}$ Some commentators

Hariton, When and How Should the Economic Substance Doctrine Be Applied?, 60 TAX L. REv. 29 (2006).

${ }^{68} A C M$ P'ship, 157 F.3d at 248-52, 252-64.

${ }^{69}$ See Merryman v. Comm'r, 873 F.2d 879, 881 (5th Cir. 1989); Sacks v. Comm'r, 69 F.3d 982, 988 (9th Cir. 1995); Keeler v. Comm'r, 243 F.3d 1212, 1217-19 (10th Cir. 2001).

${ }^{70}$ See Dewees v. Comm'r, 870 F.2d 21, 34 (Ist Cir. 1989); Dow Chem. Co. v. United States, 435 F.3d 594, 599 (6th Cir. 2006); Yosha v. Comm'r, 861 F.2d 494, 499 (7th Cir. 1988); IES Indus. Inc. v. United States, 253 F.3d 350, 353 (8th Cir. 2001); United Parcel Serv. v. Comm'r, 254 F.3d 1014, 1018 (1 l th Cir. 2001).

${ }^{71}$ See Nicole Rose Corp. v. Comm'r, 320 F.3d 282, 284 (2d Cir. 2002); Rice's Toyota World v. Comm'r, 752 F.2d 89, 91 (4th Cir. 1985).

${ }^{72}$ See, e.g., Stephen S. Bowen, The End Result Test, 72 Taxes 722 (1994); Paul, supra note 39, at 200-52, 228-29 (ultimate result), 252-54 (interdependency test).

${ }^{73}$ See generally BITTKER \& LOKKEN, supra note 9 , at 94.3 .5 , especially note 90 (areas in which doctrine is used); PAUL, supra note 39, at 202-14.

${ }^{74}$ These calls tend to accompany articles about the recent surge of corporate tax shelters. In addition to the literature mentioned infra notes $75-78$, see, e.g., Steven A. Dean \& Lawrence Solan, Tax Shelters and the Code: Navigating Between Text and Intent, $26 \mathrm{VA}$. TAx 
would codify judicial doctrines broadly, in order to deter taxpayers, especially tax shelter promoters, from egregious behavior. ${ }^{75}$ Others have noted Congress' ability to successfully incorporate doctrines elsewhere in the Code, such as in sections 355 and 368 , and thus think that Congress could act efficiently here as well. ${ }^{76}$ Still others would take an even more rigorous approach, enacting some sort of statutory antiabuse provision. ${ }^{77}$ However, the Department of the Treasury remains reluctant to support any type of codification. ${ }^{78}$ It should be noted, however, that in recent years, Congress has had the opportunity to codify judicial doctrines and, while it has taken some steps in that direction, the path to codification is hazy and much work remains to be done. ${ }^{79}$

\section{E. The One-Way Street and a Taxpayer's Ability to Disavow Form}

One final topic raised by the literature merits discussion: Is a taxpayer able to assert judicial tax doctrines? Generally, little attention is paid to who may raise judicial doctrines. One possible reason for this ennui is the perception that the taxpayer should be estopped; having cast the form of the transaction subsequently challenged by the government, the taxpayer should bear the burden of defending the legitimacy of the form chosen. ${ }^{80}$ The taxpayer should have chosen the "more favorable way" when she originally had the chance, and, in any case, the government should not be whipsawed by the taxpayer's subsequent, and contradictory, choice. ${ }^{81}$

REv. 879 (2007); Kristen Hickman, Of Lenity, Chevron, and KPMG, 26 VA. TAX REv. 905 (2007).

${ }^{75}$ See Martin J. McMahon, Jr.. Economic Substance, Purposive Activity, and Corporate Tax Shelters, Tax Notes, 94 TAX Notes 1017 (2002).

${ }^{76}$ See Ellen Aprill, Tax Shelters, Tax Law, and Morality: Codifying Judicial Doctrines, 54 S.M.U. L. REV. 9 (2001).

${ }^{77}$ See, e.g., Marvin Chirelstein \& Lawrence Zelenak, Tax Shelters and the Search for a Silver Bullet, 105 Colum. L. REv. 1939 (2005) (supporting enacting broad legislation or delegating authority to Treasury Department to draft broad regulations, to disallow noneconomic losses); George K. Yin, Getting Serious About Corporate Tax Shelters: Taking a Lesson from History, 54 S.M.U. L. RFV. 209, 220-224 (2001) (supporting taxing public corporations on income reported for financial purposes); Peter C. Canellos, A Tax Practitioner's Perspective on Substance, Form and Business Purpose in Structuring Business Transactions and in Tax Shelters, 54 S.M.U. L. REv. 47, 70-71 (2001) (supporting greater reporting and penalties).

${ }^{78}$ See, e.g., Donald Korb, Shelters, Schemes, and Abusive Transactions: Why Today's Thoughtful U.S. Tax Advisors Should Tell Their Clients to "Just Say No," in 26 TAX Strategies for Corporate ACQUisitions, Dispositions, Spin-Offs, Joint Ventures, Financings, Reorganizations \& Restructurings 189. 268 (Practicing Law Institute 2007).

${ }^{79}$ See generally. BITTKER \& EUSTICE, supra note 45, at 7 .10[8] (noting various proposals and ultimate legisiation).

${ }^{80}$ See PaUl, supra note 39; PAUL, supra note 24, at 62.

${ }^{81}$ See Comm'r v. Danielson, 378 F.2d 771, 775 (3d Cir. 1967), cert denied, 389 U.S. 858 (1967). See also Comm'r v. Nat'l Alfalfa Dehydrating \& Milling Co., 417 U.S. 134 (1974); Norwest Corp. v. Comm'r, 111 T.C. 105 (1998). See generally BITTKER \& LOKKEN, supra note 9, at 9 4.3.6-.7; Kenneth Harris, Should There Be A "Form Consistency" Requirement"? Danielson Revisited, 78 TAXes 88, 95-98 (2000); Willian S. Blatt, Lost on a One-Way Street: 
While whether the taxpayer may assert a judicial doctrine is an old problem, ${ }^{82}$ much of the discussion about it is more current. In Commissioner v. Danielson, ${ }^{83}$ the taxpayers sold their stock in a business, with some of the purchase price allocated to the stock sold and some to their covenant not to compete with the buyer. Sales proceeds allocable to the stock led to capital gain, while proceeds allocable to the covenant led to more highly taxed ordinary income. After the sale, the government challenged the taxpayers' characterization of all of their income as capital gain and the taxpayers, in part, tried to set aside the allocation to which they had agreed when they sold their stock. The Third Circuit decided in the government's favor, taxing the sellers on ordinary income from the covenant not to compete to which they had agreed, holding that:

a party can challenge the tax consequences of his agreement as construed by the Commissioner only by adducing proof which in an action between the parties to the agreement would be admissible to alter that construction or to show its unenforceability because of mistake, undue influence, fraud, duress, etc. $^{8+}$

Thus, assertion of a judicial doctrine in tax has been viewed largely as a one-way street, open to the government and, if open to the taxpayer, then under stringent conditions, such as the existence of fraud or mistake, that do not attach to the government's reliance on the same doctrines. ${ }^{85}$

Having laid the groundwork of doctrinal and normative literature about judicial tax doctrines, the article now turns to the methodology with which the database was constructed, as well as the results of and conclusions drawn from it.

\section{METHODOLOGY}

The conclusions set forth in Part IV are understood more easily against the backdrop of how the database was constructed. Therefore, that methodology is described in this portion of the Article.

The Taxpaver's Ability to Disavow Form, 70 ORE. L. Rev. 384 (1991); Saul Levmore, Recharaterization and the Nature of Theory in Corporate Tax Law, 136 U. PA. L. Rev. 1019 (1988).

${ }^{2}$ See, eg., Chirelstein, supra note 39. at 471.

${ }^{83}$ Danielson, 378 F.2d at 773.

${ }^{x+1} I d$. at 775.

${ }^{45}$ See, e.g., BrTTkir \& Lokkin, supra note 9, at 19 4.3.6-.7; Blatt, supra note 81; Levmore, supra note 81. 


\section{A. Data}

\section{Cases Examined and Period Covered}

Only cases in which decisions were rendered by judges were examined. ${ }^{86} \mathrm{~A}$ judge's decision to apply judicial doctrines is driven by facts and circumstances. The law is clear, not the facts. Thus, it seemed appropriate to examine decisions rendered by trial courts, the finder of fact in our legal system. Decisions were gleaned from an on-line search and were drawn from all three of the trial courts in the federal system in which tax cases are litigated. ${ }^{87}$ Decisions were further limited to those decided between 1993 and $2006 .^{88}$

\footnotetext{
${ }^{86}$ See generally Linda R. Stanley \& Don L. Coursey, Empirical Evidence on the Selection Hypothesis and the Decision to Litigate or Settle, 19 J. LEGAL StUD. 145 (1990) (explaining why cases may go to trial); George B. Priest \& Benjamin Klein, The Selection of Disputes for Litigation, 13 J. LEGAL STUD. 1, 4 (1984) (explaining that the reasons why parties settle or litigate "are solely economic, including the expected costs to parties of favorable or adverse decisions, the information that parties possess about the likelihood of success at trial, and the direct costs of litigation and settlement"). The database is available online at http:/law.niu.edu/law/faculty/directory/schneider/index.shtml.

${ }^{87}$ If a taxpayer pays a tax and then seeks a refund, she would litigate her case in a district court or in the Court of Federal Claims. Federal Tort Claims Act, 28 U.S.C. $\S 1346(a)(1)$ (2006) (regarding district court and Court of Federal Claims jurisdiction). If she does not pay the tax, but still litigates her liability, then she would proceed to the Tax Court. I.R.C. $\$ \S$ $7441-42,6212,6213$ (a) (regarding Tax Court jurisdiction).
}

The search was done on Westlaw, which provided better results than the comparable search on Lexis. The search term was: (substance / 10 form) (business $/ 10$ purpose) (step $/ 10$ transaction) (Gregory /10 Helvering) (economic /10 substance) (sham $/ 10$ transaction) \& DA ([the appropriate year]).

This search was made in Westlaw's database of cases decided by district courts (FTXDCT), the Tax Court (FTX-TC), and the Claims Court (FEDCL); and was done for each of the fourteen years included in the database, infra note 88 (describing period covered). See Schneider, Social Background, supra note 19, Schneider, Assessing, supra note 19, Schneider, Statutory, supra note 7, and Schneider, Empirical, supra note 7, for other searches of tax cases and how they were organized.

My earlier empirical research about trial courts in the two articles noted in the prior paragraph--Schneider, Assessing, and Schneider, Empirical-excluded the Court of Federal Claims. It is a more specialized court than the district court, but the small population of cases in this database made the ease and importance of including these cases more compelling. Only regular decisions of the Tax Court, and not its memorandum decisions, were analyzed.

${ }^{88}$ This fourteen year period is a recent and long enough period to minimize the risk that lesser and less recent periods of time might have presented. Compare Schneider, Assessing, supra note 19 (regarding a twenty year period), and Schneider, Social Background, supra note 19 (regarding a ten year period), with Staudt et al., supra note 2 (regarding an eighty-eight year period). Initially, only a five year period was used and it offered some tentative conclusions, but expansion of the years covered led to more robust results. 


\section{Units of Analysis}

Any case in which one of the five judicial doctrines already noted ${ }^{89}$ was raised was examined further. Once a case was selected, information about the case and the doctrine were entered into the database. Each reference to a doctrine in an opinion comprised a single unit of analysis. ${ }^{90}$ Information was also entered about the briefs made available on-line, if any, for the cases that were transformed into units of analysis.

\section{B. Variables and Other Information}

The variables selected were designed to illuminate the use of judicial doctrines in federal tax controversies. The information gathered about the cases included:

- the court in which the case was decided ${ }^{91}$;

- the year of the decision;

- the taxpayer's legal status ${ }^{92}$ (e.g., individual, corporation);

- was the taxpayer represented by a lawyer ${ }^{93}$;

- who won the case ${ }^{94}$; and

\footnotetext{
${ }^{89}$ See supra Introduction.
}

${ }^{90}$ Because units of analysis were organized around the appearance of doctrines, multiple references in a decision to such doctrines (or multiple references to one doctrine) led to multiple units - one for each reference.

${ }^{91}$ These courts were the Tax Court, the district court (including particular districts, although that information is not used in this article), and the Court of Federal Claims. See supra note 87.

${ }^{92}$ Taxpayers were divided into several categories, which were then reduced to four: a step intended to aid statistical analysis. These categories are: "individuals," "trusts and estates" (which included trusts and estates), "businesses" (which includes partnerships and corporations) and "other" (which included governments, nonprofit organizations and trustees).

${ }^{93}$ The taxpayer's legal representation was usually noted at the beginning of a case or sometimes, if a docket was available for the case, in the docket. For a recent article about the positive effect of taxpayers' legal representation in cases that resulted in Tax Court decisions, see Leandra Lederman \& Warren B. Hrung, Do Attorneys Do Their Clients Justice? An Empirical Study of Lawyers 'Effects on Tax Court Litigation Outcomes, 41 WAKE FOREST L. REv. 1235 (2006). See also Schneider, Social Background, supra note 19, at 226-27.

${ }^{94}$ The winner of a case was ascertained by examining multiple factors. At the very least, I did not have expectations about where my analysis would lead, which somewhat diminished the risk of bias in making these subjective judgments. It was important, of course, to dichotomize who won into two parties in order to promote statistical analysis. A decision stated by the court as in favor of the government or against the taxpayer was taken at face value, but was fortified by reading the case to confirm independently the court's conclusion. Even if the party which otherwise appeared to have won did not have all of its expectations met-for example, the taxpayer paid some portion of the tax it argued it had never owed-that party was still treated as the winner. 
- questions about judicial doctrines; including:

- which of the five judicial doctrines was raised;

- who raised the doctrine-had the government, the taxpayer, or the court, essentially said, as revealed by the judge's opinion "I'd like to have the business purpose (or the step transaction, etc.) doctrine applied (or not applied) in this decision";

- two related questions-- did the party that raised a doctrine want it applied or not, and on whose behalf did the party that raised the doctrine want the court to act,"

- did the litigants briefs cast light on any of the above questions, on doctrines they had raised but which were not used by the court, or on the one-way rule;

- which litigant prevailed in the court's decision about applying a doctrine, regardless of whether that litigant raised the doctrine or even wanted the doctrine applied on its behalf ${ }^{96}$;

- was a doctrine applied because of statutory or regulatory directive ${ }^{47}$;

- the area of tax law discussed by the court when examining the judicial doctrine under scrutiny ${ }^{98}$; and

${ }^{95}$ Because judicial doctrines are invoked to recast transactions, it was appropriate to classify a party as "not wanting a doctrine applied" when that party raised the antithesis of the doctrine's application. For example, assume that the taxpayer argued that it possessed a business purpose for the transaction under scrutiny. That case is treated as one in which the taxpayer raised a doctrine and did not want that doctrine applied.

If the taxpayer argued that it had a business purpose, it presumably would have asked the court to act on its behalf as well with respect to the doctrine. Whether that would be the case was not clear when the research began, and so both questions were asked.

${ }^{96}$ Judgments were made about this issue similar to who won a case. See, supra note 94. To follow through on the prior footnote, if the court agreed with the government about substance over form, and, therefore, decided on the government's behalf, the government prevailed in having the doctrine applied. If the court disagreed about application of the substance over form doctrine and decided on the taxpayer's behalf, the taxpayer prevailed, because the doctrine was not applied. Conversely, if the court agreed with the taxpayer that use of the business purpose doctrine was inappropriate, the taxpayer prevailed in the doctrine's use. If the court disagreed and applied the business purpose doctrine, the government prevailed in the doctrine's use.

${ }^{97} \mathrm{~A}$ doctrine was so invoked in only thirty of the 378 units of analysis, and used in all but two of them. Eighteen involved I.R.C. $\$ 6621$, six addressed $\$ 165$, two addressed $\$ 355$, and the other four examined four other sections. Because of the small number of cases in which regulatory or statutory dictates triggered use of a doctrine, current literature notwithstanding. infra Part II.D (calling for codification of judicial doctrines), no further analysis was done about a statutory directive for a doctrine's application. 
- when the taxpayer raised a doctrine, had the opinion noted that raising judicial doctrines is a one-way street and, if so, did it apply the oneway rule to prevent the taxpayer from asserting a judicial doctrine. ${ }^{99}$

The questions designed to elicit data about judicial doctrines may be illustrated with the following five examples:

Example 1. A court's opinion states that "the government argues" that the substance of a transaction, as opposed to the form the taxpayer had used, was such that the taxpayer should be denied the tax benefit it sought (e.g., an exclusion from gross income or deduction of an expense). The court sides with the government and decides in its favor, and does so by relying on the substance over form doctrine.

This case is coded as the government raising a doctrine, wanting the doctrine it had raised to be applied, and prevailing in having the doctrine applied. If the court decided not to apply the substance over form doctrine, then the case would be coded as the taxpayer having prevailed in the doctrine's use. The doctrine used, of course, is substance over form.

Example 2. An opinion says that "the taxpayer suggests" that it possessed a business purpose for the transaction in which it engaged. The court agrees, finding a business purpose for the taxpayer's action, and so allows the taxpayer its intended tax benefits.

\footnotetext{
${ }^{98}$ The areas were: "accounting," "capital assets," "business" (including two areas initially coded separately, corporate and partnership (the other, narrower, areas from which the ultimate groupings in this footnote are derived are also set forth in parentheses)), "criminal/procedure" (criminal and procedure), "deduction," "employment" (employment and pension), "estate/gift" (estate and gift), "income," and "other" (bankruptcy, excise, exempt, foreign, insurance, and natural resources). As with the type of taxpayer, supra note 92 , larger categories were established in order to enhance statistical analysis. The sections discussed by a court when examining the judicial doctrine under review were also collected, and have been used in the past. Sce generally Schneider, Social Background, supra note 19; Schneider, Assessing, supra note 19; Schneider, Statutory, supra note 7; and Schneider, Empirical, supra note 7. But this has its problems, so the general substantive area of tax law around which a case revolved - admittedly a subjective judgment - was used.

Initial research led to further highlighting of three distinct areas, to see whether cases involving judicial doctrines were aggregated in these areas. These cases involved corporate owned life insurance programs, transactions patently characterized as a tax shelter, and transactions that 1 thought might be characterized as a tax shelter (even absent the court's explicit labeling, such as foreign currency swaps, tax straddles, and programs marketed to lead their purchasers to put their assets in a thinly veiled separate entity, leading to alter ego/nominee questions).
}

Data about the judge who decided the case and about that judge's social background were also collected. Preliminary results based on this data were not meaningful, and so that line of inquiry was not pursued.

${ }^{\circ 9}$ See infra Part II.E. 
In this case, the appropriate coding is that the taxpayer raised a doctrine, the doctrine was the business purpose doctrine, the taxpayer did not want the doctrine applied, and the taxpayer prevailed in the doctrine's use. Because the taxpayer's assertion of its business purpose for the transaction negates application of the business purpose doctrine, it is appropriate to code the case as one in which the taxpayer did not want the doctrine applied. Because the doctrine was not applied-the taxpayer's litigating posture - it is also appropriate to characterize the case as one in which the taxpayer prevailed. Because the taxpayer did not want the doctrine applied, it is also appropriate to characterize the case as one in which the party that raised the doctrine--the taxpayer-wanted the court to act in its behalf and not the government's.

Example 3. In its opinion, a court articulates the importance of, and decides to apply, the sham transaction doctrine. It does not attribute the doctrine's presence in the case to either litigant, but instead discusses the doctrine as if the doctrine's application is appropriate and then applies the doctrine. The taxpayer is denied the tax benefit it sought.

The appropriate coding in Example 3 is that the court raised a doctrine, the doctrine raised was the sham transaction doctrine, the court wanted the doctrine to be applied (or, stated less awkwardly, that it intended to apply the doctrine), and that the government prevailed in the doctrine's use.

Example 4. The facts are similar to the original facts in Example 2, except that the taxpayer argues that the substance of the transaction is such that it should be allowed its intended tax benefit. This means that the taxpayer raised a doctrine, the doctrine was substance over form, the taxpayer did not want the doctrine applied, and the taxpayer prevailed in the doctrine's use.

If the court did not note the Danielson case, ${ }^{100}$ or otherwise limit the taxpayer's ability to challenge the form of the transaction, the case is coded as the "one way" rule having not been raised nor, obviously, applied. If the court did raise Danielson, but decided that its application was not appropriate, then the case is coded as the "one way" rule being raised, but not applied. If the court raised Danielson and decided that the taxpayer could therefore not vary the form it had chosen for the transaction, then the case is coded as the "one way" rule having been raised and applied.

Example 5. The facts are similar to Example 1. The parties' briefs reveal that the government argued for use of the substance over form doctrine.

${ }^{100}$ See Comm'r v. Danielson, 378 F.2d 771, 775 (3d Cir. 1967). See, e.g., supra notes 7 , 19 (regarding judges' social backgrounds). 
The case is coded as the government having raised this doctrine in briefs, that it wanted the doctrine applied, and in a manner otherwise consistent with the results in Example 1.

While these data are the crux of the Article, they are often revealed in less than ideal circumstances. Data collected sometimes may seem more obvious, as a researcher of why judges decide cases as they do may be expected to ask about the gender, race or political affiliation of ideology of the judges under scrutiny. Data that might illuminate judicial doctrines are different, however, and must be teased from the circumstances surrounding judicial doctrines--who raised them, what had the parties done with the doctrines they raised, and who prevailed in the doctrines' uses. ${ }^{101}$ Arguably, equating who was designated by a judge's opinion as having "raised" a doctrine may not reveal who actually raised it during the course of litigation. There is, however, evidence that it does, and so asking this question begins the discussion.

As is explained below, the party that most often raised a doctrine in this database was the court. Does that suggest that the taxpayer and the government repeatedly overlooked a doctrine's application? And, if not, does the court's predominant role suggest that it raised a doctrine rhetorically, and failed to credit the litigant that had raised the doctrine? In fact, a review of briefs reveals that litigants rarely raised doctrines. ${ }^{102}$ It also quickly became apparent during research that sometimes a party

\footnotetext{
${ }^{101}$ Inferences are drawn from the data. See Lee Epstein \& Gary King, The Rules of Inference, 69 U. CHI. L. REV. I (2002).

${ }^{102}$ See infra fig.l (showing the court raised the doctrine more than the government or the taxpayer) and note 111 (briefs).

Nor does procedural posturing-e.g., who must raise an issue in litigation, what failure to do so means-bar equating who appears to have raised a judicial doctrine, according to an opinion, with who actually raised it during the course of litigation. The rules surrounding federal tax litigation are noted below. Generally, they encourage simple pleading and are designed primarily to put one's opponent on notice, so they stop short of requiring a litigant to plead a judicial doctrine.
}

Refund litigation. A taxpayer seeking a refund is subject to the Federal Rules of Civil Procedure, either because it chooses to litigate in the district court-which is governed by the Rules - or because it chooses to litigate in the Court of Federal Claims, whose rules incorporate the Rules. See Gerald A. Kafka \& Rita A. Cavanaugh, Litigation of FEdERAL CIVIL TAX CONTROVERSIES I 15.06[3] (2d ed. 1997). The taxpayer generally has the burden of proving both that the Internal Revenue Service's assessment was incorrect and that the overpayment of taxes it claims was correct. See id. 16.01[1]. Nevertheless, the rules of pleading are generous, and a taxpayer must file a complaint that is simple, concise and direct, whether in the district court or the Court of Federal Claims. Fed. R. Civ. Proc. 8(e)(1). Ct. Fed. Cl. R. 8(e)(1). All "that is required is sufficient notice of the relief sought and the grounds on which the relief is based" to withstand the government's "motion for dismissal or for judgment on the pleadings." KaFKa \& CAVANaugh 17.02[1]. In addition to containing denials or statements about the government's lack of knowledge about matters averred in the complaint, the government's answer also must contain any affirmative defenses, such as estoppel, fraud or res judicata. Fed. R. Civ. Proc. 8(c), 9(b)-(e). Ct. Fed. Cl. R. 8(c), 9(b). Finally, it should be noted that the rules of both courts allow pleadings to be liberally amended. KaFKa \& CAVANAugh 17.05 . 
raised a doctrine, only to suggest that application of the doctrine was not apt (e.g., a taxpayer who argued that it had a business purpose). These are just a few of the nuances of the indirect nature of this evidence. Nevertheless, useful information was mined from the data.

The opinions were taken at face value, a decision the importance of which is underscored in the prior paragraph. Precisely because it was impossible to determine whether the source of the court's activity in raising a doctrine was caused by the litigants' inattention, the court's rhetorical posturing, or some other reason, it was more reliable simply to note who, using the court's language, had raised a doctrine"the taxpayer says" or "the government argues" or nothing-instead of guessing what the court might have intended, but failed, to say.

\section{Statistical Analyses}

Statistical significance for relationships in the results was assessed by appropriate tests. ${ }^{103}$ Binary logistic regression was used to establish relationships between the independent and dependent variables. ${ }^{104}$

Tax Court litigation. A taxpayer contesting a tax liability in the Tax Court faces rules that are slightly different from the above rules. After receiving a notice of deficiency from the Service (about its tax), the taxpayer may petition the Tax Court to have its deficiency redetermined. The burden of proving its case lies with the taxpayer, except for affirmative defenses, the burden of proof for which lies with the government. See T. Ct. R. 142(a)(1). As in refund cases, supra, averments in a pleading must be simple, concise, and direct, T. Ct. R. 31 (b), although they must be more detailed than in refund cases. See Kafka \& Cavanaugh 9 5.07. Even if the pleadings are somehow deficient, they can be corrected by an amendment of the party, either once as of right before the responsive pleading or thereafter by the court's leave or consent of the adverse party; leave shall be "given freely when justice so requires." T. Ct. R. 41(a). Affirmative averments in the government's answer not specifically denied by the taxpayer in its reply will be deemed admitted. T. Ct. R. 37(c).

These rules encourage putting one's opponent on notice, not pleading every point in one's case. They do not diminish the possibility that either litigant might raise an issue such as a judicial doctrine during the course of litigation.

${ }^{103}$ Relationships between different variables can always be generated. However, statistical significance enables one to distinguish between those relationships which arise randomly from those that are less the subject of chance. Statistical significance is "designed to allow us to make statements about the probability that hypothetical relationships actually occur"; it permits the inference that two variables are related, in the population and in the same manner in the sample, and not merely the result of random association. DAVID KNOKE ET AL., Statistics for Social. Data ANalysis 21-22, 142 (4th ed. 2002). The Pearson $X^{2}$ test was used for cross-tabulations of dichotomous variables (e.g., who raised a doctrine and whether that party wanted a doctrine applied).

Statements in this Article about statistical significance refer to testing at $\mathrm{p}$ levels $\leq .05$. While literature frequently states the "amount" of significance, e.g., p level $\leq .05$, or $\leq .01$, this Article merely sets forth the results that are statistically significant, with respect to the crosstabulations. This Article simply characterizes them as such, without attempting to illustrate the level of significance, in an attempt make the discussion less confusing. Because more specific statements about statistical significance may assist the reader in understanding logistic regressions, the levels of significance are noted infra Part IV.F. See Schneider, Assessing, supra note 19, at 490 n.61; James J. Brudney et al., Judicial Hostility Toward Labor Unions? Applying the Social Background Model to a Celebrated Concern, 60 Oню ST. L.J. 1675, 1709 n. 121 (1999) (discussing 0.05 and 0.01 levels of testing for significance). 


\section{REsults}

\section{A. Introduction}

Three-hundred seventy-eight units of analysis were derived from 275 cases, as some decisions raised more than one doctrine. ${ }^{105}$ The results drawn from the data sustain the article's hypothesis that judicial doctrines are not monopolized by the government. As is explained below in greater detail, the government, the court, and the taxpayer, all raised judicial doctrines and it was the court, not the litigants, who raised doctrines most frequently. It also appears that the court's active role in raising doctrines occurred because the litigants tended not to raise them. As might be expected, both of the litigants-the government and the taxpayer-tried to have judicial doctrines applied for its own benefit but each found that it was more likely to prevail in a doctrine's use when its opponent had raised the doctrine than when it did. Substance over form was used more than other doctrines. Specific doctrines can be associated with specific areas of tax law. The one-way street rule, theoretically making it difficult for taxpayers to argue that they can vary the form of a transaction, was largely ignored by the court and the government. Finally, circumstances enable prediction of which doctrines lead to the government or the taxpayer prevailing in a doctrine's use.

General observations can be made about the data. ${ }^{106}$ For example, the units of analysis were drawn, in declining amounts, from cases decided by the district courts, the Tax Court, and the Court of Federal Claims. Most of the taxpayers were characterized as individuals or businesses or, to a lesser extent, as estates or trusts. The government prevailed in a doctrine's use about twice as much as the taxpayer, and also won about twice as many cases as the taxpayer (regardless of who prevailed in a doctrine's application). Taxpayers were almost always represented by lawyers. ${ }^{107}$

But these observations do not do justice to the data. Instead, a better narrative is presented when the data is associated with certain themes. Therefore, the following discussion is organized around some of the variables used to mine information from the data about judicial doctrines.

\footnotetext{
${ }^{104}$ Logistic regression permits each independent variable to be isolated "while controlling for the influence of other independent variables and while measuring the magnitude of the influence." Schneider, Social Background, supra note 19, at 227.

${ }^{105}$ See supra text following note 89 (raising doctrines). Most decisions raised only one judicial doctrine. Only sixty-eight of the 275 cases raised doctrines multiple times. For methodological reasons, only the 207 instances in which one court raised one doctrine were used in the logistic regressions. See infra note 144.

${ }^{106}$ See infra app., tbls.A-D (displaying graphs representing much of this data).

${ }^{107}$ See supra note 93 (discussing legal representation in tax cases). See also, e.g., Schneider, Social Background, supra note 19, at 223 (discussing more pro se representation in other tax litigation).
} 


\section{B. Who Raised a Doctrine and Did the Party Raising a Doctrine Want the Court to Apply the Doctrine?}

Who raised a judicial doctrine is the first question posed by the data, the answer to which illuminates flaws in the accepted wisdom. The results reveal that the taxpayer raised doctrines assertively, rather than passively acting as the party against whom the government always asserted doctrines. The court, however, was the party most likely to raise a doctrine. Therefore, what happened when the court acted influenced other results that flowed from asking which party had raised a doctrine. The court appears to have raised doctrines because the litigants failed to do so. Even though a litigant raised a doctrine, presumably for its benefit, its opponent frequently was the litigant on whose behalf the court then applied that doctrine.

Any participant in litigation - the taxpayer, the government or the court itselfcould raise a doctrine for consideration. When the taxpayer or the government raised a doctrine (regardless of whether that party also wanted to have the doctrine applied), it seems reasonable to believe that each of the litigants must have done so to advance its case, and that the court was prompted by a desire to press a particular point.

As Figure 1 reveals, it was the court that most frequently raised a doctrine.

Figure 1. Party Raising a Doctrine, by Percentages $(\mathrm{N}=378)$

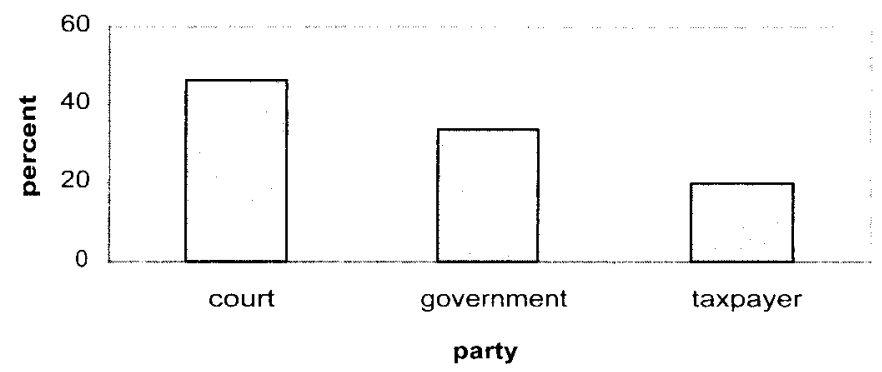

The court raised a doctrine almost half the time in all units of analysis, and in the remaining units, the taxpayer raised a doctrine more than half as frequently as the government, underscoring the benefit taxpayers saw in raising doctrines. ${ }^{108}$ Figure 1 also signals that what courts did about judicial doctrines was critical, given the large percentage of units of analysis in which it was the court that raised a doctrine.

As noted ${ }^{109}$ the court's predominant role in raising doctrines theoretically might cloud inferences drawn from the data. Arguably, it might be unrealistic to believe that the court always raised a doctrine on its own initiative and that the government and the taxpayer were consistently silent. ${ }^{110}$ But the on-line documents

\footnotetext{
${ }^{108}$ How the parties were served by the court raising doctrines' use is not answered by fig. 1 , and therefore must be inferred through results set forth in fig.2, infra.

${ }^{109}$ See supra text following note 102.

${ }^{110} \mathrm{Id}$. Even in Gregory v. Helvering, 293 U.S. 465 (1935), the government said that the transaction "was without substance and must be disregarded." 293 U.S. 465, 467 (1935). But
} 
accompanying the cases from which the units of analysis were derived tend to suggest that the most likely explanation for the court's activity was that it was acting in a void created by the litigants.

On-line documents accompanied about half the units of analysis. In about threequarters of the units in which documents appeared, the documents were summary and most likely only a docket entry. Substantive discussion appeared in forty-six units of analysis (just over ten percent of all 378 units). Even when litigants' briefs were reproduced, ${ }^{111}$ judicial doctrines that the court's subsequent opinion discussed were raised in these briefs in only twelve units, a mere three percent of all units. In other words, the litigants' briefs inevitably failed to address doctrines subsequently mentioned in opinions.

What happened in the thirty-plus briefs in which the litigants engaged in substantive discussion that was not directed towards the judicial doctrines raised in the court's opinion? Litigants made focused arguments, relying on specific authorities such as statutes, cases, regulations and rulings. Because the litigants did not address judicial doctrines in these briefs, it follows that the court must have been the party that raised a doctrine.

When who raised a doctrine was contrasted with other aspects about the use of judicial doctrines, a fuller picture emerges. While the government raised doctrines in a way resonant with the accepted wisdom-raising them frequently, almost always seeking to have them applied-taxpayers did not. Taxpayers frequently raised doctrines, sometimes trying to have them applied, but frequently defensively, arguing that they should not be applied. The critical player in who raised a doctrine was the court, which signaled that it intended to act, when rendering its decision, on the taxpayer's behalf in only a quarter of the units of analysis. ${ }^{12}$

Another noteworthy aspect of who raised judicial doctrines was that even litigants tended to fail to have the doctrines applied by the court in the way they intended. ${ }^{113}$ The taxpayer persuaded the court to apply a doctrine in a way that benefited it twenty-two percent of the time it raised a doctrine. The government was more successful--it persuaded the court to apply a doctrine in a way that benefited it fifty-one percent of the time it raised a doctrine--but that percentage still does not reinforce the accepted wisdom about judicial doctrines, since the government lost with respect to a doctrine's application almost as frequently as it prevailed when it

the court, to judge by the opinion, was the sole source of the conclusion that the transaction was without "business or corporate purpose." $I d$. at 469.

${ }^{11}$ On-line research does not reveal whether the briefs were all or only some of those submitted during the litigation or how they were chosen for reproduction. Many of the documents pertained to discovery, and thus shed no light on legal theories used to advance the litigants' cases.

112 The court, like the government, almost always wanted the doctrines it raised to be applied. Of all the times the government and the taxpayer raised a doctrine, only once did either litigant not want a doctrine applied on its own behalf. (The cross-tabulation for this result was statistically significant.) It seems counterintuitive for a litigant to argue against a doctrine's application on its behalf, and these two cases may best be understood as aberrant situations.

${ }^{113}$ See also infra fig. 2 (displaying results for a party raising doctrine and also wanting the doctrine applied). 
was the party that raised a doctrine. Again, the litigant that prevailed with respect to a doctrine's application was strongly influenced by what happened when the court raised a doctrine. The government prevailed twice as many times as did the taxpayer in this circumstance, such that, again, an overall bias in favor of the government is revealed when contrasting who prevailed in a doctrine's application with who raised a doctrine. ${ }^{114}$

Another way in which to adduce information about judicial doctrines in federal tax cases is to examine whether a party, having raised a doctrine, wanted the court to apply the doctrine. It might seem obvious that a party raising a doctrine also wants it applied, e.g., the government arguing that the substance of a Gregory-type distribution was a dividend, despite its technical characterization as a reorganization. But a party could also argue that application of the doctrine it raised is not appropriate, as would implicitly occur when a taxpayer argued that it had a business purpose for its Gregory-type distribution. What might be said about a party that wanted a doctrine it had raised to be applied, or not to be applied?

Generally, the government sought the application of doctrines it raised more than either of the other parties and the taxpayer sought to avoid application of doctrines more than either of the other parties. Wanting a judicial doctrine that a party had raised also to be applied was coupled with the specific doctrine used in the opinion. Substance over form was used more than any other doctrine when the party that raised the doctrine also wanted it applied, while business purpose was used more than other doctrines when the party raising a doctrine did not want it applied.

As Figure 2 reveals, the government and the court rarely raised doctrines without intending to have them applied. This result conforms to that aspect of the common wisdom that suggests, as taxpayers structured the form of the transaction, the government or the court tried to set that form aside. In contrast, the taxpayer raised doctrines in order to argue their inapplicability (e.g., the aforementioned existence of a business purpose and, therefore, negation of the business purpose doctrine) more frequently.

\footnotetext{
${ }^{114}$ These results are statistically significant. When the same questions were asked, but for units of analysis divided into the three constituent courts in which taxpayers could litigatedistrict courts, the Tax Court, and the Court of Federal Claims, see supra note 87-the statistically significant results replicated the above results with some variations. The taxpayer raised a doctrine somewhat more in the Claims Court than was revealed in figure 1, the government less in that court, but the results in the other two courts were simitar to the resulis at large. The taxpayer also raised doctrines defensively more in the Claims Court, sixty percent of the time. While the government continued to avoid using doctrines it had raised defensively, it did so most in the Claims Court as well, ten percent of the units of analysis in which it had raised a doctrine. The above results were statistically significant. The only statistically significant data for the cross-tabulation of which party had raised a doctrine and which litigant prevailed was for the district courts, where the results tended to replicate those set forth in the text regarding the entire set of data.
} 
Figure 2. When Party Raising a Judicial Doctrine Also Wanted the Doctrine Applied $(\mathbf{N}=\mathbf{3 7 8})^{115}$

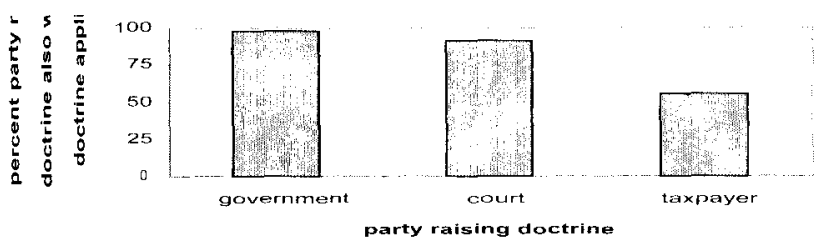

Taxpayers raising doctrines in order to have them applied suggests that taxpayers perceived that they could use doctrines offensively. Some doctrines cannot be asserted by the taxpayer; a taxpayer cannot argue that a transaction should be recast from the original form it chose into a better one because the transaction was a sham, lacked economic substance or a business purpose. But the other doctrinessubstance over form and the step transaction doctrines-may be asserted by the taxpayer to recast a transaction as well as the government, because they can be used to justify a decision on either litigant's behalf.

That taxpayers raised doctrines in order to avoid having them applied also intimates that taxpayers understood that the government's use of doctrines could be parried. Even if the taxpayer cannot use the sham transaction, economic substance or business purpose doctrines offensively, it still can use them defensively, raising these doctrines in order to argue that they should not be applied. The results reveal the taxpayer understood its ability to use the doctrine that cut both ways, substance over form, offensively, and the defensive use of the business purpose doctrine. ${ }^{116}$ Use of the remaining doctrines, however, does not reinforce this perception. Each of the remaining three doctrines - sham, economic substance, and step transactionwere raised by a party only to have the party argue that they were inapplicable roughly fifteen percent of the time. Therefore, there is no ready explanation why doctrines were raised only to then be avoided. ${ }^{17}$

${ }^{115}$ These results are statistically significant.

${ }^{116}$ The doctrine raised most frequently by a party arguing that the doctrine's application was not appropriate was the business purpose doctrine; that party called for not applying the business purpose doctrine thirty-seven percent of the time the doctrine was raised. In contrast, the doctrine raised most frequently by a party seeking to have the doctrine applied was substance over form; that party argued not to apply that doctrine only five percent of the time. These results were for all parties that raised doctrines and then argued for or against the doctrines, not for whether the taxpayer, government or court had raised doctrines and then argued that they did not apply, because those results were not statistically significant.

${ }^{117}$ The party raising other doctrines and arguing that it should not be applied did so twenty percent of the time for the economic substance doctrine, nineteen percent of the time for the step transaction doctrine, and thirteen percent of the time for the sham transaction doctrine. These results are statistically significant. While the finer question of which party raised a particular doctrine and sought to not have the doctrine applied did not lead to statistically significant results, one might infer, given the large number of times that the taxpayer assumed this posture, that this was most frequently the taxpayer.

When the results were examined for each of the courts, modest changes occurred. The taxpayer sought to avoid application of doctrines it had raised somewhat less in the district 


\section{Judicial Doctrines Used}

A second way to assess how parties relied on judicial doctrines is to examine which doctrines the parties raised. The specific doctrines used are cross-tabulated against the parties that raised the doctrines in Figure 3. The extent to which the government, the court and the taxpayer used each judicial doctrine is set forth in this figure so that, for example, one may see that the court used substance over form in about sixty percent of all units of analysis in which it raised a doctrine (and the government and the taxpayer about twenty and thirty percent, respectively) by looking at the bars at the extreme right side of the figure.

Figure 3. Doctrine Used and Party Raising a Doctrine $(\mathrm{N}=378)^{1 / \mathrm{k}}$

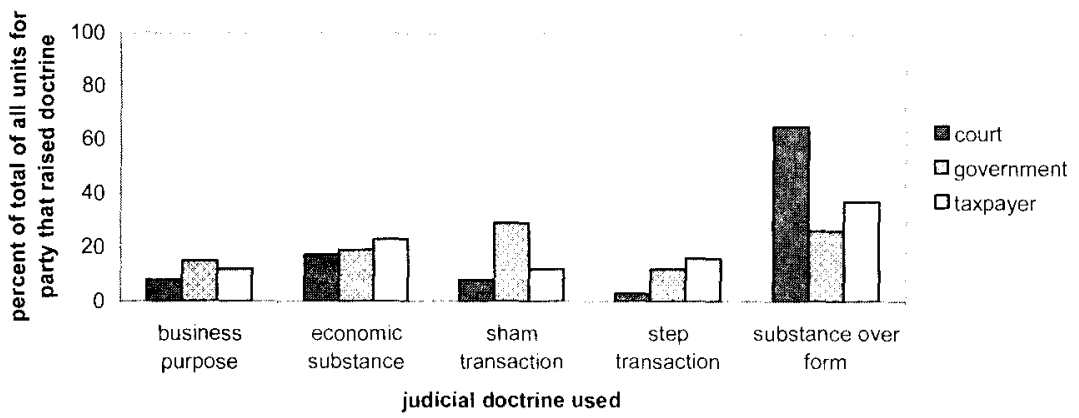

One of the more striking results set forth in Figure 3 is the heavy reliance on substance over form. As one looks at the set of columns on the far right of the figure, it is apparent that a large percent of the doctrines used in the court's opinion, regardless of which party raised a doctrine, was substance over form. Indeed, substance over form failed as the preeminent doctrine only when the party raising the doctrine was the government. ${ }^{119}$

One way in which to interpret this use of substance over form is that every party, especially the court, recognizes the flexibility that this doctrine presents. Other doctrines require more specific findings: the absence of a specific purpose, for the business purpose and sham transaction doctrines; or facts, for the economic substance or step transaction doctrines. While substance over form is, of course, factually grounded, it alone among judicial doctrines lacks relatively objective standards. ${ }^{120}$

The court's predominate use of substance over form--almost two-thirds of the time-resonates with the court as the party most likely to raise a doctrine. As noted,

court and the Tax Court than it had when all the courts were aggregated; the government and the court sought to have doctrines they raised applied even more in these two courts. In contrast, the taxpayer sought to avoid application of doctrines it raised even more in the Court of Federal Claims, while the government and court somewhat less. These results are statistically significant in all three courts.

${ }^{118}$ These results are statistically significant.

${ }^{119}$ The frequency of the doctrines used in all units of analysis, for all parties and not just for each, is set forth infia app., tbl.E. Substance over form was used the most and the step transaction doctrine the least.

${ }^{120}$ See supra Part II.C. 
there is some evidence that litigants' arguments gravitate towards certainty: cases, regulations, legislative history, etc., instead of judicial doctrines. ${ }^{121}$ If use of doctrines rests primarily with the court, then the court might also prefer substance over form, the doctrine least constrained by ascertainable standards, in order to maximize its flexibility when applying doctrines and deciding cases. The taxpayer also benefits from uncertainty, as it struggles to escape the form of the transaction it crafted and so it, too, can therefore benefit by using form over substance. In comparison, the government-motivated by its desire to compel the taxpayer to submit to the form of the transaction it originally chose-has less reason to use substance over form.

Another revealing aspect of the doctrines used was that the government relied less on any one doctrine than the court or the taxpayer. This outcome might reflect the government's conformance, again, to the common wisdom-raise doctrines in order to have them applied-in contrast to the court and the taxpayer, who appear to have raised doctrines, respectively, because the litigants tended not to do so or in negation of that wisdom. The taxpayer also prevailed most in a doctrine's application when that doctrine was the business purpose doctrine. ${ }^{122}$ This result fortifies the earlier observation that the taxpayer raised the business purpose doctrine more, only to argue that it was not applicable. Figure 3 reveals that the taxpayer had great success maintaining this position, raising and then distinguishing the business purpose doctrine from the case at issue. The government prevailed most in a doctrine's application when that doctrine was substance over form. Substance over form's benefiting the government may be explained by the court's heavy reliance on that doctrine compounded with the court's primary role in raising doctrines and its favoring the government when it did raise doctrines. ${ }^{123}$ While one might argue that different areas of tax law favored different doctrines--e.g., the sham transaction doctrine was used more in alter ego-nominee cases than other doctrines ${ }^{124}$ - that point of view cannot explain why the various parties raised doctrines differently. Each party had equal access to each area--the taxpayer could have sought to distinguish the sham doctrine in an alleged alter ego case as easily as the court or the government could have raised it-so something else must have prompted the variance.

When questions surrounding the doctrines used were examined in each of the three courts under observation, the results replicated the more general findings, although the results also lacked statistical significance. The parties raising the doctrines had statistical significance in the Tax Court and the district court, but not in the Court of Federal Claims, and the litigant that prevailed was statistically significant only in the district court.

\section{Areas of Law}

One of the more intriguing aspects about the data assembled for this article is the chance to confirm that judicial doctrines appear in specific areas of tax law, as the

\footnotetext{
${ }^{121}$ See supra text following note 111.

${ }^{122}$ Fifty-nine percent in statistically significant results.

${ }^{12 .}$ Sixty-nine percent in statistically significant results. See supra fig. 2.

${ }^{124}$ See infra notes $129-30$.
} 
literature suggests, such as corporate tax, estate planning, and matters surrounding families. This connection between doctrines and different areas of tax is one of the few "hard" observations about judicial tax doctrines in the literature and, other than authors' impressions that such associations exist, no evidence exists to prove or disprove this assertion. ${ }^{125}$ While the data suggest that doctrines appear more in certain areas, no evidence buttresses the alleged connection between doctrines and areas of law. To some extent, this gap may exist because contrasting the literature and the data is an inexact process. The observation is dated, the evidence is not, and data-including the areas of law in which tax controversies occur-may have changed over time; one conclusion is impressionistic and the other empirical; and the two sets of results have been measured by different areas of law.

Having noted these warnings, the data set forth in Figure 4 reveal that judicial doctrines arose a greater number of times in two areas of law-what is deductible and procedural and criminal tax matters - than in business tax (which combines corporate and partnership tax). ${ }^{126}$ Indeed, the first two categories accounted for half of all the times that doctrines were raised (roughly twenty-five percent in each), while only ten percent of all the cases in which doctrines were used involved business tax. After business tax, the next area in which doctrines were most frequently raised involved employment tax, followed by estate planning (which combined estate and gift tax cases). ${ }^{127}$

Figure 4. Areas of Tax Law Raised in Units of Analysis by Percentage $(\mathrm{N}=378)$

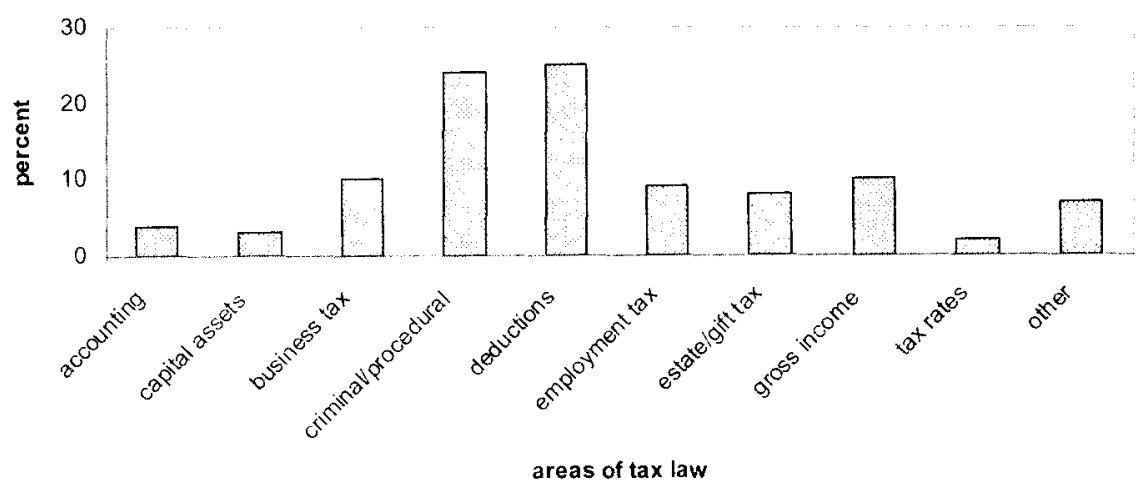

Even more compelling than whether doctrines could be linked to areas of tax law is which doctrines were used in which areas. ${ }^{128}$ Substance over form was used the greatest percentage of times in cases involving accounting and capital assets (relative to substance over form's use in other areas) and least in cases involving business tax or the proper rate of tax. In contrast, the step transaction doctrine was used the

${ }^{125}$ See supra note 36.

${ }^{126}$ These results are statistically significant.

${ }^{127}$ See supra text accompanying note 98 (discussing areas of tax law categorized for this article).

${ }^{128}$ These results are statistically significant. 
greatest percentage of times in cases concerning the rate of tax and least in those about accounting (relative to the doctrine's use in other areas of law). The sham transaction doctrine was used the greatest percentage of times in procedural and criminal tax cases, economic substance in cases about deductions, and business purpose in cases involving accounting, estate planning and capital assets.

It is difficult to assess the meaning of the results between judicial doctrines and areas of law because there is no benchmark for comparison other than, of course, the outgrown judgments about the areas in which any doctrine appears. At the very least, however, the view about doctrines' use is outdated, and must be revised to reflect doctrines' actual prevalence in various areas. Furthermore, certain doctrines may be associated with certain areas because of how case law has developed. For example, economic substance may simply be the doctrine used most to disallow deductions if and when those deductions have no basis for existing other than to reduce someone's tax. ${ }^{129}$ Similarly, the sham transaction doctrine was used in alter ego-nominee tax cases, which were characterized as involving procedural tax matters: that may account for the preeminence of this doctrine in cases about procedural and criminal tax matters. Another possible explanation is that doctrine use is shaped by necessity, with the litigants and the court (the party that primarily raised doctrines ${ }^{130}$ ) doing whatever was necessary to win or to manage litigation.

\section{E. The One-Wan Street Rule}

Another untested perception about judicial doctrines is that they lie on a one-way street, raised by the government or court, but allowed to the taxpayer only when it can establish fraud or duress in its choosing the original form of the transaction. ${ }^{131}$ Evidence gleaned from the database suggests that this truism is incorrect, because the one-way street rule was not frequently invoked, either in substance or by citing the cases usually associated with the rule.

The taxpayer raised doctrines in seventy-four units of analysis. Even if the need for fraud or duress could have been invoked only in the cases in which the taxpayer sought to apply a doctrine--..-which it did forty-one times of these seventy-four instances- the one-way street rule was raised in only thirteen of these cases, less than a third of the forty-one cases in which it could and should have been raised. ${ }^{132}$ Because the rule must be invoked absolutely, the only way in which to explain the failure to invoke the rule in the other two-thirds of the authority is that the rule was ignored.

\footnotetext{
${ }^{120}$ See supra Part II.C.4.

${ }^{130}$ See supra fig. 1.

${ }^{131}$ See supra Part II.E.

${ }^{132}$ When raised, the rule was applied eleven times to preclude the taxpayer's altering the form of the transaction.
} 


\section{F. Assessing Cause and Effect in the Database}

Regressions permit the association of independent and dependent variables. ${ }^{133}$ More than merely describing what happened, they permit one to infer what might occur-to predict the likely outcome of events caused by certain factors in a database. Logistic regressions offer the benefit of isolating the effect of each independent variable while controlling for the influence of other independent variables, and simultaneously measuring the magnitude of the variables' influence. In other words, these regressions are able to tell us what matters and what matters most.

An illustrative logistic regression for the database created for this Article is set forth in the Appendix. ${ }^{134}$ The independent variables used in the logistic regression ${ }^{135}$ were:

- whether the party that had raised a doctrine wanted the doctrine applied;

- which party raised the doctrine ${ }^{130}$;

${ }^{133}$ See KNOKE ET AL., supra note 103, at 235. Predictive statistics permit drawing inferences between causes and effects within a database, such as whether the party that raised a doctrine or the taxpaycr's representation by a lawyer could be associated with the taxpayer prevailing in a particular doctrine's application.

${ }^{134}$ See app., tbl.F.

${ }^{135}$ The independent variables that have more than two categories--for example, the party that had raised a doctrine could have been the government, the taxpayer, or the court had to be parsed into two categories by using "dummy" variables in order to test the effect of each possible scenario (i.e., government versus non-government (taxpayer and court), taxpayer versus non-taxpayer, court versus non-court, court versus non-court (government and taxpayer)) in the logistic regression. See KNOKE El AL., supra note 103, at 27I-78. The variables for the type of taxpayer and the doctrine used in the court's opinion also have multiple categories, and so they were rendered into (dichotomous) dummy variables as well.

${ }^{136}$ See supra text accompanying notes $95-99$ (discussing these variables). It is important to ascertain the multicollinearity of the independent variables. Multicollinearity occurs when there is a high correlation between independent variables and it may lead to a less accurate prediction of the outcome. See KNOKE ET AL., supra note 103, at 268. Some of the independent variables led to higher correlations. These include:

* when the type of taxpayer was a business or an individual - a correlation of .820 ;

* when the party raising the doctrine was the court and either the taxpayer or the government- .585 and .641 , respectively:

* when the party raising the doctrine was the taxpayer or the government and on whose behalf the party that had raised the doctrine wanted the court to act- .604 and .485 , respectively; and

* when the doctrine used was substance over form and either economic substance or the sham transaction doctrine- .534 and .450 , respectively.

What constitutes multicollinearity is unclear, Schneider, Social Background, supra note 19, at $229 \mathrm{n} .73$, but in the past I have used a benchmark of $+/-.500$, id. KNOKE ET AL., supra note 103 , at 268 , and suggest that $+/ . .800$ reveals high multicollinearity. For the reasons just 
- whether the taxpayer was represented by a lawyer;

- the taxpayer's legal status ${ }^{137}$;

- $\quad$ in whose behalf did the party that raised the doctrine want the court to act; and

- which doctrine did the court apply (or not apply) in rendering its decision. ${ }^{\text {i.38 }}$

The dependent variable was which party prevailed in a doctrine's application. ${ }^{139}$

The results were not robust, so limited conclusions may be drawn from them. ${ }^{140}$ To the extent that the results were statistically significant, they appeared to cluster in one of two ways. First, some could be characterized as being connected to the assertiveness with which parties postured for doctrines' applications. For example, a statistically significant result occurred between the party that raised a doctrine and the litigant that prevailed in a doctrine's application. The government or the

noted and the minimization, the highest correlation of the independent variables used was .325 .

Eliminating just one of the dichotomous variables for which party had raised a doctrine would have sufficed for purposes of creating a dummy variable. Except when the party raising a doctrine was the taxpayer (versus not the taxpayer such as the court or the government), high correlations were generated against two other independent variables--the government (versus not the government) and the litigant on whose behalf the party that raised the doctrine wanted the court to act. So both types of parties who raised doctrines (the taxpayer and the government) were both eliminated in order to avoid multicollinearity.

${ }^{137}$ When the type of taxpayer was a business (versus not a business) the independent variable was eliminated because it occurred less frequently than the independent variable when the type of taxpayer was an individual (versus not an individual). This elimination also satisfied the need for a dummy variable. See infra app., tbl.B.

${ }^{138}$ While substance over form was used more than other doctrines, eliminating it from the independent variables most easily eliminated higher correlations and also satisfied the need for a dummy variable.

${ }^{139}$ Who won the case also could have been used as the dependent variable, but the article examines judicial doctrines and so using who prevailed instead of who won seemed more appropriate. On the other hand, parties that prevailed in a doctrine's application also tended, in a statistieally significant manner, to win cases, so the results may not have been that different had the other dependent variable been used.

${ }^{1+40}$ Regressions may be refined by testing for interactions among the independent variables. One tests for interactions by looking for associations between variables when controlling for other variables. A simple exanple might be to assume in a particular election that younger women of a particular racial group vote for Candidate $B$. Is it the voters' age, race, or possibly geographic location that influence the outcome? Testing for interactions, therefore, may help in understanding the effect of independent variables on the outcome.

Here, the outcome of the government or the taxpayer prevailing could have been caused by several independent variables, and so testing for interactions enables one to suggest which of these factors was influential. Unfortunately, the interactions were not robust and so they are not discussed. 
taxpayer's raising a doctrine was associated with the taxpayer's prevailing in the doctrine's application, and the court's raising a doctrine with the government prevailing. Therefore, the taxpayer's raising a doctrine worked on its behalf, while the government's raising a doctrine did not. An even more focused result occurred when asking on which litigant's behalf a doctrine had been raised, because that outcome could be associated with that litigant prevailing in the doctrine's use. A party raising a doctrine and asking the court to act on the government's behalf was predictive of the government prevailing with respect to that doctrine. Conversely, the party asking the court to apply the doctrine on behalf of the taxpayer also was predictive of the taxpayer prevailing. The government or the taxpayer rarely asked the court to apply a doctrine in favor of its opponent, so the litigants asserting doctrines on their own behalf was connected with their prevailing in having those doctrines applied. ${ }^{141}$ The key player, however, remained the court.

The other statistically significant associations in the regression were among the doctrines used. Use of the business purpose and the sham transaction doctrines were associated with the taxpayer's prevailing with respect to these doctrines' applications. Because these doctrines could not be applied on the taxpayer's behalf, ${ }^{142}$ either the taxpayer must have raised them but argued their inapplicability, or the government must have argued unsuccessfully for their application. In contrast, use of the step transaction doctrine was associated with the government's prevailing in the doctrine's use. ${ }^{143}$

What do these two sets of results mean? Conclusions drawn from the latter setthe doctrines used-seem more apparent. One distinction between the doctrines that favored the taxpayer-business purpose and sham-and the one that benefited the government-step transaction-is that the first two can be applied only on behalf of the government. Arguably, the all or nothing approach demanded of these doctrines could have led to these associations that favored the taxpayer. One may also infer that the evidence offered to support these doctrines favored the taxpayer, given the taxpayer's success with them. The association of the step transaction doctrine with the government prevailing in the doctrine's use is more enigmatic. It could be argued that the other doctrine that could be applied to justify a decision on either litigants' behalf--substance over form-led to results that were too dispersed between the taxpayer and the government for a pattern to appear. Why, then, did only one of these two have results that even approached statistical significance?

The meaning of the other results-those associated with the assertiveness with which they were argued - is less clear. To a limited extent, they sustain the truism that judicial doctrines are applied to benefit the government. The court raised doctrines more than the government and the taxpayer and the greater frequency with

${ }^{141}$ See supra note 112.

${ }^{142}$ See supra text following note 115.

${ }^{143}$ Furthermore, the association of this doctrine with the government's prevailing in the doctrine's use only approached statistical significance.

Another set of logistic regressions, the independent variables of which were identical to those used in the Appendix but for the exclusion of economic substance and inclusion of substance over form. The results were similar to those discussed in the text regarding the regression in the Appendix, although use of the sham transaction doctrine became statistically significant. 
which the government instead of the taxpayer prevailed in a doctrine's application can be associated with the court's frequency in raising doctrines. But the taxpayer's raising a doctrine was connected to its prevailing in a doctrine's application and to this extent the common wisdom rings falsely. Litigants inevitably raised doctrines for their own benefit, and so the association of the government's raising doctrines with the taxpayer prevailing may suggest that the government chose its cases poorly. Inevitably, however, there is something contradictory about the results. Litigant's raising doctrines was associated with the taxpayer prevailing, yet a party's raising a doctrine and asking the court to apply it on behalf of a litigant was associated with that litigant's prevailing.

\section{CONCLUSION}

This Article begins with the premise that there is a common wisdom, one promoted by traditional literature, that judicial tax doctrines are inevitably invoked by the government or the court for the benefit of the government. The taxpayer profits from formal compliance with the terms of a statute, and so the common wisdom seems reasonable. This Article hypothesizes, however, that the common wisdom is wrong and that judicial doctrines are not used exclusively for the benefit of the government. Instead, the landscape drawn by the database created for this article suggests that judicial doctrines are asserted vigorously, by taxpayers as well as the government and courts. More than the other two parties, taxpayers raised doctrines and argued that they not be applied. Doctrines were applied more for the benefit of the government than the taxpayer, but were, it should be underscored, applied on behalf of the taxpayer. Substance over form was the judicial doctrine used most often, and specific doctrines appeared more in certain areas of substantive law. The theoretical importance of the one-way rule notwithstanding, it did not seem to be raised much. And, finally, various causes led to one litigant or the other prevailing in a doctrine's use. A litigant was more likely to prevail if the party raising a doctrine wanted it applied on that party's behalf. The taxpayer's prevailing in a doctrine's application was associated with the taxpayer or the court raising a doctrine and the government's prevailing was associated with the court raising a doctrine. Furthermore, use of the business purpose and sham transaction doctrines were associated with the taxpayer prevailing in those doctrines' use and the step transaction doctrine with the government's prevailing in that doctrine's use.

More empirical research must be done about judicial doctrines in tax, to fill the gap between what is thought and what in fact occurs. Doing so can lead to a greater understanding of how these doctrines are used and which litigant they benefit. 


\section{APPENDIX A}

Table A Frequency of units of analysis in different courts $(\mathrm{N}=378)$

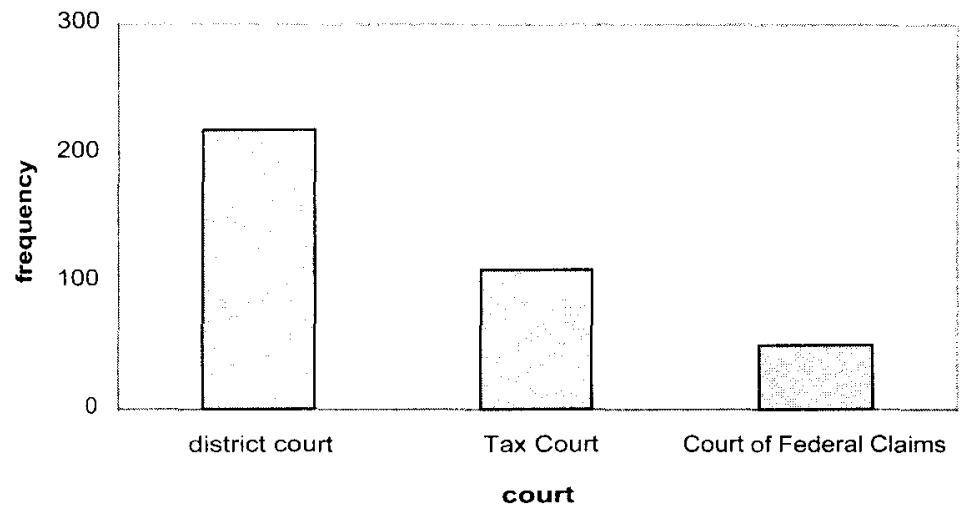

Table B Frequency of Appearance of Different Types of Taxpayers $(\mathrm{N}=378)$

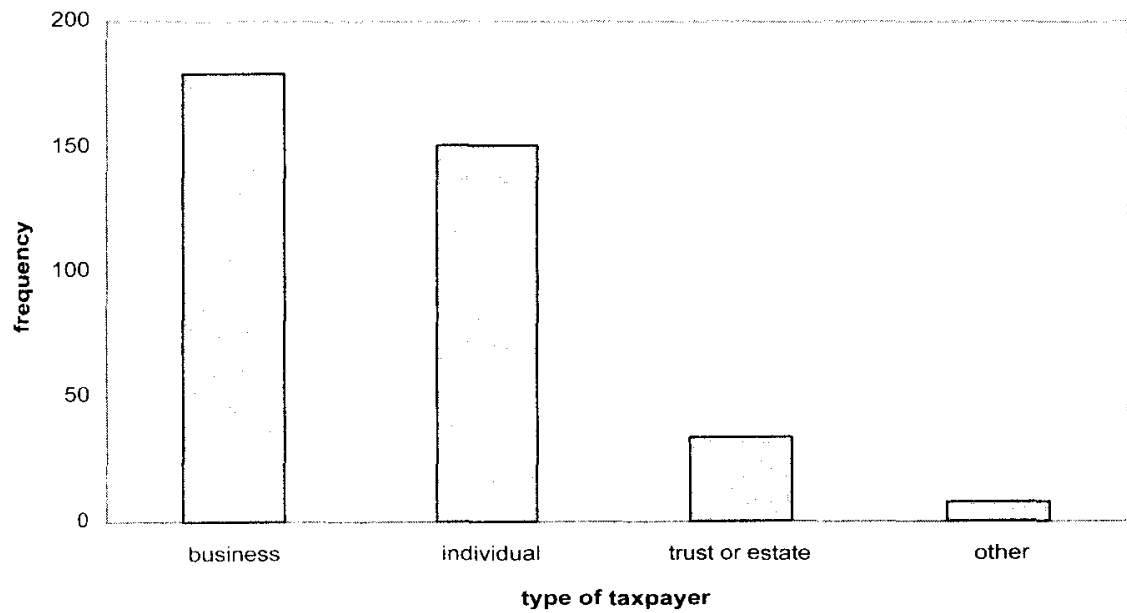


Table C Frequency of Litigants Winning Cases $(\mathrm{N}=378)$

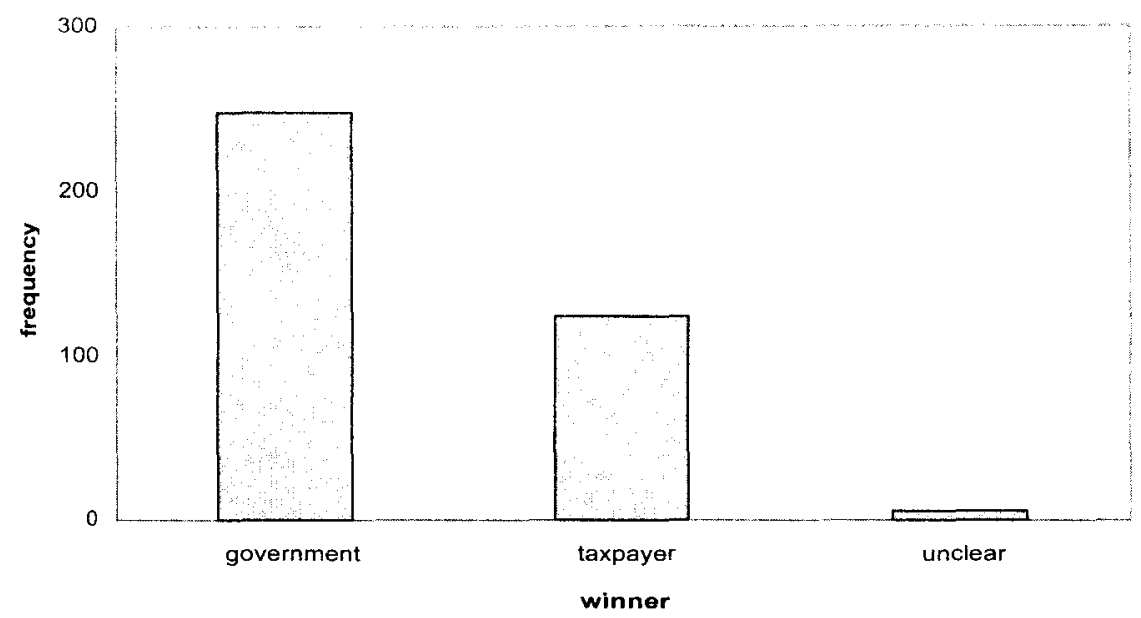

Table D Frequency of Litigants Prevailing in Application of Doctrines $(\mathrm{N}=378)$

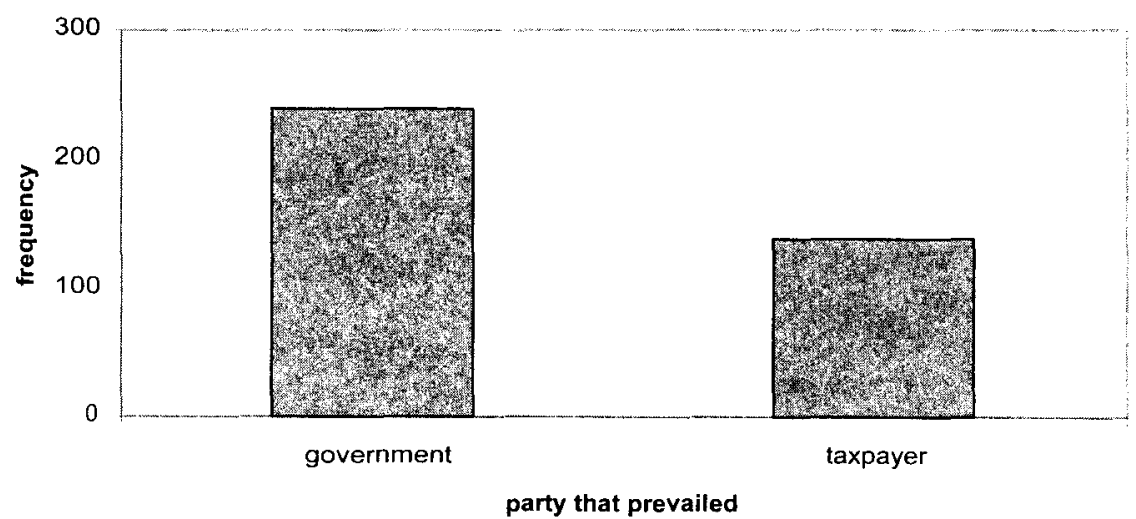


Table E Frequency of Doctrines Used $(\mathrm{N}=378)$

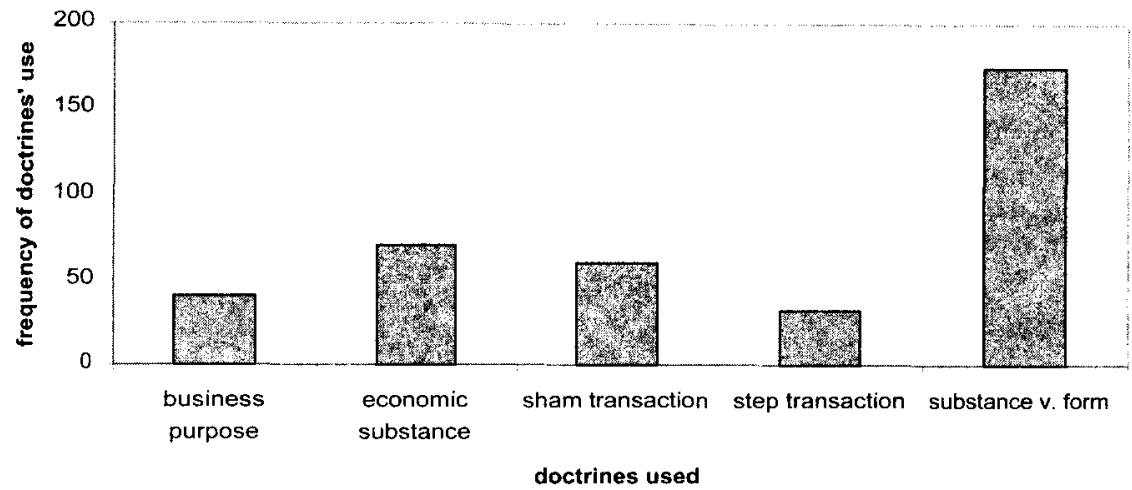

Table F. Logistic Regression Between Various Independent Variables and Who Prevailed in a Doctrine's Use $(\mathrm{N}=207)$

\begin{tabular}{|c|c|c|c|c|}
\hline & B & S.E. & Significance & Exp. $\beta$ \\
\hline $\begin{array}{l}\text { Did the party that raised a doctrine } \\
\text { also want the doctrine applied } \\
(0=\text { no, } 1=\text { yes })\end{array}$ & .942 & .622 & .130 & 2.565 \\
\hline $\begin{array}{l}\text { Party raising doctrine } \\
(0=\text { government } \text { or taxpayer, } \\
l=\text { court })\end{array}$ & 1.248 & .426 & .003 & .287 \\
\hline $\begin{array}{l}\text { Taxpayer had lawyer }(0=\text { no lawyer, } \\
1=\text { lawyer })\end{array}$ & .906 & .638 & .155 & .404 \\
\hline $\begin{array}{l}\text { Type of taxpayer }(0=\text { business, } \\
\text { individual, } 1=\text { trust/estate/nonprofit } \\
\text { or government) }\end{array}$ & .513 & .717 & .474 & 1.670 \\
\hline $\begin{array}{l}\text { Type of taxpayer }(0=\text { business, } \\
\text { trust/estate/ nonprofit or } \\
\text { government, } I=\text { individual })\end{array}$ & .060 & .394 & .879 & .942 \\
\hline $\begin{array}{l}\text { On whose behalf did party that } \\
\text { raised doctrine want court to act } \\
(0=\text { taxpayer, } 1=\text { court })\end{array}$ & 2.175 & .395 & .000 & 8.798 \\
\hline $\begin{array}{l}\text { Doctrine used }(0=\text { economic } \\
\text { substance, sham, step transaction, } \\
\text { substance over form, } 1=\text { business } \\
\text { purpose) }\end{array}$ & 2.218 & .847 & .009 & .109 \\
\hline
\end{tabular}




\begin{tabular}{|c|c|c|c|c|}
\hline $\begin{array}{l}\text { Doctrine used }(0=\text { business purpose, } \\
\text { sham, step transaction, substance } \\
\text { over form, } 1=\text { economic substance })\end{array}$ & .513 & .557 & .357 & 1.671 \\
\hline $\begin{array}{l}\text { Doctrine used }(0=\text { business purpose, } \\
\text { economic substance, sham, } \\
\text { substance over form, } 1=\text { sham })\end{array}$ & 1.345 & .594 & .024 & .261 \\
\hline $\begin{array}{l}\text { Doctrine used }(0=\text { business purpose, } \\
\text { economic substance, sham, step } \\
\text { transaction, } 1=\text { step transaction })\end{array}$ & 2.033 & 1.151 & .077 & 7.640 \\
\hline
\end{tabular}

${ }^{144}$ The column titled "significance" sets forth the statistical significance of the relationship between the independent variable and the dependent variable. For a discussion of statistical significance, see supra note 103.

The columns for $\beta$ and Exp. $(\beta$ ) state the same fact differently. $\beta$ indicates the effect of an independent variable on the logarithmic probability of the dependent variable occurring. If the Exp. $(\beta)$ is greater than one, the presence of the independent variable-for example, the party wanting the doctrine applied-means that the dependent variable is more likely to occur than not. If the result for this independent variable is statistically significant, that makes the association more meaningful. See supra note 103 (discussing statistical significance). If the Exp. ( $\beta$ ) is less than one, the presence of the independent variable - for example, the use of the business purpose doctrine as opposed to all other judicial doctrines-means that the dependent variable is less likely to occur than not (and, again, this result is enhanced by its statistical significance). Exp. ( $\beta$ ) can also be said to state the odds ratio. See KNOKE ET AL., supra note 103, at 161-63, 309-11 (discussing odds and odds ratios). For example, when the type of taxpayer to whom a doctrine was applied was a trust or an estate, the odds ratio of the government's prevailing in a doctrine's use increased about 1.7 times. And when the party raising a doctrine also wanted the doctrine applied, because that $\operatorname{Exp} .(\beta)$ is greater, about 2.6, then it could be said that the latter variable increased the odds ratio of the doctrine being applied in the government's behalf even more and would therefore be even more powerfully associated with the government prevailing than the former independent variable. Unfortunately, neither Exp. ( $\beta$ ) is statistically significant. Therefore these two results are less meaningful.

Understanding how the variables are coded is part of the process of reading these regressions. Positive and negative effects (relative to one) connote direction, but only by reference to how the variables are coded. To continue with the first illustration in the prior paragraph, the Exp. ( $\beta$ ) of 1.7 is predictive of two results. First, the government will prevail when the taxpayer in the unit of analysis is a trust or estate, and not an individual or a business because that independent variable - the characterization of the taxpayer-is coded $0=$ taxpayer who is business or individual, $1=$ taxpayer who is trust or estate, and the dependent variable is coded $0=$ taxpayer prevailing in a doctrine's use, $1=$ government prevailing in a doctrine's use. Second, the government prevails when the taxpayer is a trust or estate, because of the same coding.

The Exp. $\beta$ of .109 with respect to use of the business purpose doctrine is predictive of two results as well: Using the business purpose doctrine is predictive of the taxpayer's prevailing in a doctrine's use because of the coding (independent variable, $0=$ doctrine used is one other than business purpose, $\mathrm{I}=$ doctrine used is business purpose, and dependent variable, 
Table G. Frequencies of Independent Variables in Table $E(N=207)^{145}$

\begin{tabular}{|c|c|c|}
\hline $\begin{array}{l}\text { Independent } \\
\text { variables/frequencies }\end{array}$ & & \\
\hline $\begin{array}{l}\text { Did the party that raised a } \\
\text { doctrine also want the } \\
\text { doctrine applied }\end{array}$ & No $-11 \%$ & Yes $-89 \%$ \\
\hline Party raising doctrine & $\begin{array}{l}\text { Government or taxpayer } \\
-40 \%\end{array}$ & Court $-60 \%$ \\
\hline Taxpayer had lawyer & No $-12 \%$ & Yes $-88 \%$ \\
\hline Type of taxpayer: & $\begin{array}{l}\text { Not a trust or estate - } \\
91 \%\end{array}$ & Trust or estate $-9 \%$ \\
\hline- & Not an individual $-47 \%$ & Individual $-53 \%$ \\
\hline $\begin{array}{l}\text { On whose behalf did party } \\
\text { that raised doctrine want } \\
\text { court to act }\end{array}$ & Taxpayer $-38 \%$ & Government $-62 \%$ \\
\hline Doctrine used: & $\begin{array}{l}\text { Not business purpose - } \\
94 \%\end{array}$ & Business purpose $-6 \%$ \\
\hline- & $\begin{array}{l}\text { Not economic substance } \\
-85 \%\end{array}$ & $\begin{array}{l}\text { Economic substance - } \\
15 \%\end{array}$ \\
\hline- & Not a sham $-89 \%$ & Sham $-11 \%$ \\
\hline- & $\begin{array}{l}\text { Not step transaction - } \\
94 \%\end{array}$ & Step transaction $-6 \%$ \\
\hline $\begin{array}{l}\text { Dependent variable - } \\
\text { taxpayer prevailed in } \\
\text { doctrine's use/government } \\
\text { prevailed }\end{array}$ & $\begin{array}{l}\text { Taxpayer prevailed - } \\
28 \%\end{array}$ & $\begin{array}{l}\text { Government prevailed -- } \\
73 \%\end{array}$ \\
\hline
\end{tabular}

$0=$ taxpayer prevailing in a doctrine's use, $1=$ government prevailing in a doctrine's use). Also, not using the business purpose doctrine is predictive of the government prevailing in the doctrine's use, again because of the same coding.

The $\mathrm{N}$ is smaller in the logistic regressions than in the descriptive statistics due to use of units of analysis in which a court used multiple doctrines, supra note 105. Otherwise the risk occurs that the sampling would not be representative.

${ }^{145} \mathrm{~Tb}$ I.G sets forth the frequencies with which the independent variables and the $f$ dependent variable appeared in tbl.F. 
